Elżbieta Kryńska*, Łukasz Arendt ${ }^{* *}$

ROZDZIA

\title{
Adaptacja systemów kształcenia zawodowego do wymogów nowoczesnych rynków pracy w regionie łódzkim
}

\section{Potrzeby nowoczesnych rynków pracy a region łódzki}

Rynek pracy województwa łódzkiego zmienia się pod wpływem czynników o charakterze krajowym i międzynarodowym, czy wręcz globalnym. W ostatnim okresie, istotny wpływ na łódzki rynek pracy miał i nadal ma światowy kryzys finansowy, którego skutki odczuwane są (na szczęście w mniejszym natężeniu niż w innych krajach) również w Polsce. Jednakże w perspektywie długookresowej należy spodziewać się powrotu gospodarki światowej na ścieżkę wzrostu - w rezultacie podstawowe wyzwania, przed którymi stanie rynek pracy województwa łódzkiego, będą wiązały się z reakcją na główne determinanty kreujące rozwój rynków pracy w skali globalnej. Do takich głównych uwarunkowań należy zaliczyć trzy megatrendy:

- procesy globalizacji;

- rozwój technologiczny, w szczególności technologii informacyjnych i telekomunikacyjnych,

- starzenie społeczeństwa.

Globalizacja istotnie wpływa na wielkość popytu na pracę, wzmacnia dualizację rynków pracy i równocześnie prowadzi do rozwoju gospodarki opartej na wiedzy - w epoce globalizacji jednym z najbardziej mobilnych czynników produkcji staje się wiedza kumulowana pod postacią kapitału ludzkiego. Dynamiczny rozwój technologiczny oddziałuje z kolei nie tyle na wielkość popytu na pracę, ile na jego strukturę - zmianie ulegają profile kwalifikacyjne pracobiorców. Nowe technologie wymagają wyższego poziomu kwalifikacji - przede

\footnotetext{
* Profesor zwyczajny, Katedra Polityki Ekonomicznej, Wydział Ekonomiczno-Socjologiczny, Uniwersytet Łódzki. E-mail: ekryn@uni.lodz.pl

** Adiunkt, Katedra Polityki Ekonomicznej, Wydział Ekonomiczno-Socjologiczny, Uniwersytet Łódzki. E-mail: larendt@uni.lodz.pl
} 
wszystkim kwalifikacji ogólnych, nie związanych z pojedynczym podmiotem gospodarczym ${ }^{1}$. Wiele tradycyjnych zawodów staje się zbędnych. Szybki postęp i dyfuzja nowych rozwiązań technologicznych, którym towarzyszą nowe formy organizacji pracy prowadzą dalej do wyraźnego spadku zapotrzebowania na kadry nisko- i niewykwalifikowane. Rozwój technologii skutkuje również procesami delokalizacji - przemysł przetwórczy, a przede wszystkich usługi nierynkowe stają się w coraz większym stopniu uniwersalne i globalne, przy czym traci na znaczeniu miejsce, w sensie lokalizacji geograficznej, w którym są produkowane. Natomiast procesy starzenia społeczeństwa w krajach wysoko rozwiniętych (w szczególności w Europie Zachodniej) powodują, że wydłużeniu będzie ulegał czas pozostawania aktywnym zawodowo. Pociaga to za sobą konieczność ciagłego uzupełniania kompetencji, gdyż moralna deprecjacja kapitału ludzkiego ${ }^{2}$ następuje $\mathrm{w}$ coraz szybszym tempie, $\mathrm{w}$ związku $\mathrm{z}$ dynamicznym rozwojem technologicznym.

Te wszystkie procesy sprawiają że następują zmiany paradygmatu pracy $\mathrm{z}$ industrialnego na postindustrialny (informacyjny). Dla industrialnego paradygmatu pracy, dominującego jeszcze kilka lat temu w wysoko rozwiniętych gospodarkach, charakterystyczne było zatrudnienie pracownicze, w pełnym wymiarze czasu pracy, w standardowych godzinach pracy, przy zapewnieniu zabezpieczenia socjalnego gwarantowanego przez państwo. Postindustrialny (informacyjny) paradygmat pracy całkowicie zmienił hierarchię wartości - nastapiła przestrzenna dyslokacja, praca w wielu przypadkach może być wykonywana wszędzie, o każdej porze, a czas pracy stał się elastyczny (Tabela 1).

Wszystkie megatrendy, kreujące postindustrialny paradygmat pracy, wskazują na dwie istotne kwestie. Po pierwsze, nowoczesne rynki pracy wymagają rosnącej elastyczności, aby możliwie szybko reagować na zachodzące zmiany na rynkach produktów, usług i rynkach finansowych. Po drugie, rośnie znaczenie kapitału ludzkiego, który staje się czynnikiem warunkującym utrzymanie konkurencyjności na globalnym rynku. Dla województwa łódzkiego oznacza to konieczność rozwijania kapitału ludzkiego, a równocześnie tworzenia takich warunków, aby wysoko wykwalifikowane kadry pozostawały na obszarze województwa i by nie następował drenaż mózgów do innych regionów Polski czy za granice.

${ }^{1}$ Zgodnie z modelem kapitału ludzkiego Beckera mowa tu o uniwersalnym i przenośnym kapitale ludzkim.

${ }^{2}$ Moralna deprecjacja kapitału ludzkiego (z ang. economic obsolence) przejawia się w niedostosowaniu umiejętności zasobów pracy do wymagań stawianych przez pracodawców - mimo iż zasoby pracy dysponują określonym zasobem kapitału ludzkiego, jest on ,przestarzały” i nieprzystający do potrzeb nowoczesnego rynku pracy. Może to przejawiać się w tym, że na rynku pracy popyt na dane umiejętności/zawody się skończył, w rezultacie ich rynkowa wartość spadła do zera (por. P. Allaart, M. Kerkhofs, J. de Kning, Skills Obsolescence and Technological Progress: an Empirical Analysis of Expected Skill Shortages, The Economics of Skills Obsolescence, 2002, Vol. 21, s. 119-138). 
Tabela 1. Wybrane determinanty pracy czasów industrialnych i postindustrialnych

\begin{tabular}{|c|c|}
\hline Industrialne cechy pracy & Postindustrialne cechy pracy \\
\hline 1. Stałe zatrudnienie $\mathrm{z}$ umowa o prace & 1. Elastyczne formy zatrudnienia \\
\hline 2. Zatrudnienie $\mathrm{w}$ jednym miejscu przez całe życie & 2. Częste zmiany miejsca pracy, wzrost \\
\hline 3. Standardowe godziny pracy ( $8 \mathrm{~h}$, od $8 \mathrm{~d}$ & znacz \\
\hline 4. Zatrudnienie na pełny etat ( 40 godz./tydz.) & żnicowany czas pracy, \\
\hline $\begin{array}{l}\text { 5.Zabezpieczenia socjalne, gwarantowane przez } \\
\text { państwo }\end{array}$ & $\begin{array}{l}\text { okresy wzmożonej aktywności przepla- } \\
\text { tane przestojami }\end{array}$ \\
\hline 6. Silna współpraca wewnątrz organizacji, oparta & 4. Mobilność i przestrzenna dyslokacja \\
\hline $\begin{array}{l}\text { na spotkaniach twarzą w twarz, a kontakty ze- } \\
\text { wnętrzne skanalizowane w specjalnych wydzia- }\end{array}$ & $\begin{array}{l}\text { 5. Indywidualna odpowiedzialność za } \\
\text { zabezpieczenie socjalne }\end{array}$ \\
\hline łach (zaopatrzenie, dystrybucja) & 6. Elastyczne systemy komunikacji \\
\hline $\begin{array}{l}\text { 7. Dominacja hierarchicznych powiązań w zakła- } \\
\text { dzie pracy }\end{array}$ & $\begin{array}{l}\text { i kooperacji równocześnie wewnątrz, jak } \\
\text { i z otoczeniem firmy }\end{array}$ \\
\hline \multirow[t]{2}{*}{$\begin{array}{l}\text { 8. Głęboka specjalizacja zawodowa, kwalifikacje } \\
\text { na całe życie }\end{array}$} & $\begin{array}{l}\text { 7. Praca projektowa, spłaszczenie struktur } \\
\text { organizacyjnych }\end{array}$ \\
\hline & $\begin{array}{l}\text { 8. Kluczowe kompetencje, ciagłe doskona- } \\
\text { lenie zawodowe, edukacja ustawiczna } \\
\text { przez całe życie }\end{array}$ \\
\hline
\end{tabular}

Źródło: K. B. Matusiak, Ł. Arendt, E. Bendyk, Kadry przyszłości [w:] K. B. Matusiak, J. Kuciński, A. Gryzik (red.), Foresight kadr nowoczesnej gospdoarki, PARP, Warszawa 2009, s. 127.

Zachodzące na nowoczesnych rynkach pracy przemiany w sposób spójny opisuje model flexicurity. Flexicurity ma za zadanie połączyć dwa konkurencyjne wobec siebie elementy: elastyczność (flexibility) i bezpieczeństwo (security) pracowników i przedsiębiorstw, sprzyjając konkurencyjności, zatrudnieniu i zadowoleniu z pracy, poprzez zachowanie równowagi między elastycznością a bezpieczeństwem $^{3}$. W dokumentach Unii Europejskiej przyjęto, że dla osiagnięcia równowagi między elastycznością i bezpieczeństwem na rynku pracy konieczne jest spełnienie czterech warunków, które nazywa się również elementami lub filarami pojęcia flexicurity:

- dostępność właściwych porozumień umownych,

- aktywna polityka rynku pracy (ALMP),

${ }^{3}$ E. Kryńska, Równowaga między elastycznościq i bezpieczeństwem na polskim rynku pracy. Jak osiagnać flexicurity? [w:] Flexicurity - między elastycznościq a bezpieczeństwem na rynku pracy, Biblioteka Monitora Prawa Pracy, Wydawnictwo C. H. Beck, Warszawa 2008, s. 7-21.

${ }^{4}$ ALMP - Active Labour Market Policy - celem tej polityki jest zwiększenie zatrudnienia i spadek bezrobocia dzięki bezpośredniemu oddziaływaniu na szanse znalezienia pracy przez osoby nimi objęte, poprzez zwiększanie popytu na pracę (subsydiowanie zatrudnienia, roboty publiczne), a także usprawniające funkcjonowanie samego rynku (pośrednictwo pracy, doradztwo zawodowe). Część programów realizuje także postulaty polityki społecznej (zapewnienie dochodu, przeciwdziałanie wykluczeniu społecznemu). OECD i UE od początku lat 90 . XX w. rekomendują aktywną politykę rynku pracy w przekonaniu o jej skuteczności w redukcji bezrobocia. 
- systemy uczenia się przez całe życie (LLL) ${ }^{5}$, oraz

- nowoczesne systemy zabezpieczenia socjalnego.

Filar uczenia się przez całe życie oraz częściowo filar aktywnej polityki rynku pracy bezpośrednio odnoszą się do problematyki rozwoju kapitału ludzkiego - jest to istotny element zapewniający bezpieczeństwo pracownika na rynku pracy - jest to bezpieczeństwo zdolności do zatrudnienia, rozumiane jako pewność świadczenia pracy u różnych pracodawców.

Analizy związane z budowaniem polskiego modelu flexicurity wykazały, iż to właśnie filar uczenia się przez całe życie, obok aktywnej polityki rynku pracy, powinien być głównym komponentem polskiego modelu, przy czym tworzeniu nowych i rozbudowie istniejących instytucji edukacyjnych musi towarzyszyć dostosowywanie programów i form nauczania adekwatnych do potrzeb i możliwości zasobów pracy, a także do zapotrzebowania zgłaszanego ze strony pracodawców ${ }^{6}$. Ta uwaga odnosi się również do systemu kształcenia, jaki powinien powstać $\mathrm{w}$ najbliższych latach $\mathrm{w}$ województwie łódzkim, a który powinien kształcić kompetencje poszukiwane na nowoczesnym rynku pracy.

Jak pokazują wyniki różnych analiz, nowoczesne rynki pracy w coraz większych stopniu przywiązują wagę do wiedzy i umiejętności, które nie są związane z wykonywaniem danego zawodu, czy pracą na danym stanowisku. Już w 2006 r. instytucje Unii Europejskiej zdefiniowały listę kompetencji kluczowych rozumianych jako wiedza, umiejętności i postawy, które są potrzebne na obecnym etapie rozwoju społeczno-gospodarczego do samorealizacji i rozwoju osobistego, bycia aktywnym obywatelem, integracji społecznej i zatrudnienia ${ }^{7}$. Na liście tej znalazły się

- porozumiewanie się w języku ojczystym;

- porozumiewanie się w językach obcych;

- kompetencje matematyczne i podstawowe kompetencje naukowo-techniczne;

- kompetencje informatyczne;

- umiejętność uczenia się;

- kompetencje społeczne i obywatelskie;

- inicjatywność i przedsiębiorczość; oraz

- świadomość i ekspresja kulturalna.

${ }^{5}$ LLL - Lifelong Learning Programme - Program „Uczenie się przez całe życie” jest kolejną inicjatywą w obszarze edukacji i nauki, którą przyjął Parlament Europejski i Rada Unii Europejskiej w dniu 15 listopada 2006 r. decyzją nr 1720/2006/WE. Obejmuje on okres od 2007 do 2013 roku, będzie w nim uczestniczyć 31 krajów: 27 krajów Unii Europejskiej, kraje EFTA i EOG Islandia, Norwegia i Lichtenstein oraz Turcja jako kraj kandydujaccy.

${ }^{6}$ E. Kryńska (red.), Flexicurity w Polsce. Diagnoza i rekomendacje, Ministerstwo Pracy i Polityki Społecznej, Departament Rynku Pracy, Warszawa 2009, s. 200.

${ }^{7}$ Zalecenie Parlamentu Europejskiego i Rady z dnia 18 grudnia 2006 r. w sprawie kompetencji kluczowych w procesie uczenia się przez całe życie (2006/962/WE). 
Praktycznie wszystkie kompetencje kluczowe można zaliczyć, zgodnie z modelem kapitału ludzkiego Beckera, do kapitału uniwersalnego lub przenośnego.

$\mathrm{Na}$ liście najważniejszych kompetencji, jakie będą poszukiwane na polskim rynku pracy w perspektywie do 2020 r., opracowanej w ramach projektu Foresight kadr nowoczesnej gospodarki również znalazły się kompetencje w pełni lub częściowo przenośne, przy czym zwrócono uwagę, iż w nieco inny sposób będzie kształtował się popyt na kompetencje kadry kierowniczej i kompetencje pracowników niższych szczebli (Tabela 2$)^{8}$.

Tabela 2. Lista oczekiwanych kompetencji kadry kierowniczej oraz pracowników niższego szczebla

\begin{tabular}{|c|c|c|c|}
\hline $\begin{array}{c}\text { Oczekiwane kompetencje kadry } \\
\text { kierowniczej }\end{array}$ & $\begin{array}{l}\text { Procent } \\
\text { wskazań }\end{array}$ & $\begin{array}{l}\text { Oczekiwane kompetencje } \\
\text { pracowników }\end{array}$ & $\begin{array}{l}\text { Procent } \\
\text { wskazań }\end{array}$ \\
\hline $\begin{array}{l}\text { Umiejętność funkcjonowania w } \\
\text { otoczeniu międzynarodowym }\end{array}$ & $93,3 \%$ & „Przekwalifikowalność” i mobilność & $91,1 \%$ \\
\hline $\begin{array}{l}\text { Praca w zespole, zarządzanie zespo- } \\
\text { łami }\end{array}$ & $91,1 \%$ & tycznych & $82,2 \%$ \\
\hline Kreatywność i przedsiębiorczość & $91,1 \%$ & Znajomość języków obcych & $80,0 \%$ \\
\hline $\begin{array}{l}\text { Zarządzanie wiedzą i infobroker- } \\
\text { stwo }\end{array}$ & $91,1 \%$ & \begin{tabular}{|l}
$\begin{array}{l}\text { Umiejętność } \\
\text { otoczeniu mi }\end{array}$ \\
\end{tabular} & $73,3 \%$ \\
\hline $\begin{array}{l}\text { Komunikacja interpersonalna, } \\
\text { autoprezentacja }\end{array}$ & $88,9 \%$ & $\begin{array}{l}\text { Wykorzystani } \\
\text { nych }\end{array}$ & $71,1 \%$ \\
\hline ków obcych & $88,9 \%$ & $\begin{array}{l}\begin{array}{l}\text { Komunikacja inter } \\
\text { prezentacja }\end{array} \\
\end{array}$ & $71,1 \%$ \\
\hline tot & $84,4 \%$ & $\begin{array}{l}\text { Praca w zespole, zarządzanie zespo- } \\
\text { łami }\end{array}$ & $71,1 \%$ \\
\hline $\begin{array}{l}\text { Wykorzystanie technologii mobil- } \\
\text { nych }\end{array}$ & 8 & Kreatywność i przedsiębiorczość & $68,9 \%$ \\
\hline $\begin{array}{l}\text { „Przekwalifikowalność” i mobil- } \\
\text { ność }\end{array}$ & $\%$ & Ugru & $62,2 \%$ \\
\hline Ochrona własności intelektualnej & 7 & $\begin{array}{l}\text { Zarządzanie wiedzą i } \\
\text { stwo }\end{array}$ & $\%$ \\
\hline Ugruntowane podstawy matematyki & $77,8 \%$ & Ochrona własności intelektualnej & $55,6 \%$ \\
\hline
\end{tabular}

Źródło: K. B. Matusiak, Ł. Arendt, E. Bendyk, Kadry przyszłości [w:] K. B. Matusiak, J. Kuciński, A. Gryzik (red.), Foresight kadr nowoczesnej gospdoarki, PARP, Warszawa 2009, s. 128-129.

W przypadku pracowników zatrudnionych na stanowiskach menadżerskich, do trzech najważniejszych kompetencji zaliczono: umiejętności funkcjonowania w otoczeniu międzynarodowym (nawiązując tym samym do zachodzących procesów globalizacji, które mają również wymiar regionalny i lokalny), pracę

${ }^{8}$ Lista najbardziej poszukiwanych kompetencji została opracowana przy wykorzystaniu metody delfickiej i panelu ekspertów w ramach projektu „Foresight kadr nowoczesnej gospodarki” zrealizowanego na zlecenie Polskiej Agencji Rozwoju Przedsiębiorczości w 2009 r. 
w zespole oraz kreatywność i przedsiębiorczość. Natomiast dla pracowników liniowych najważniejsza jest elastyczność - zdolność do zmiany zawodu i miejsca pracy, znajomość podstaw technologii informacyjnych i telekomunikacyjnych oraz znajomość języków obcych.

W Foresighcie kadr nowoczesnej gospodarki zidentyfikowano również tzw. branże i zawody przyszłości, które zdaniem ekspertów biorących udział w badaniu będą charakteryzowały się ponadprzeciętnymi wzrostami. Wśród branż przyszłości znalazły się: informatyka i usługi internetowe, automatyka i robotyka, budownictwo i inżynieria lądowa, biotechnologia, medycyna i usługi opiekuńcze, usługi okołobiznesowe, turystyka i rekreacja, przemysł spożywczy, logistyka i inżynieria transportu, inżynieria środowiska oraz transport lotniczy i kolejowy. Natomiast wśród zawodów przyszłości wymieniono, między innymi, teleinformatyków, mechatroników, biotechnologów, menadżerów szpitalnych, e-bankowców, coachów, doradców zawodowych, negocjatorów, czy menadżerów ds. podróży (travel manager).

Należy podkreślić, że wiele z wymienionych branż przyszłości nie jest związanych z nowoczesnymi technologiami i wysoką innowacyjnością, a ich perspektywiczny rozwój jest wynikiem rosnącego popytu na pewnego rodzaju usługi wynikające ze zmian ekonomiczno-społecznych (między innymi starzenia się społeczeństwa i zmian w strukturze konsumpcji).

Z podobnego założenia wyszedł zespół Regionalnego Obserwatorium Rynku Pracy (RORP) w Łodzi, który na przełomie 2009 i 2010 r. przeprowadził badanie „Branże przyszłości. Perspektywy rozwoju zasobów pracy w regionie łódzkim". Branże przyszłości w badaniu tym zdefiniowano jako te obszary działalności gospodarczej, które wykazują symptomy rozwoju, przy czym nie było istotne, czy badane podmioty gospodarcze stosuja jakiekolwiek rozwiązania innowacyjne, czy też nie ${ }^{9}$. W rezultacie w badanej grupie przedsiębiorstw znalazły się podmioty (w sumie 50) z branży budowlanej, handlowej, transportu, energetyki, elektrotechniki, poligrafii, farmaceutycznej, AGD, ochrony, tłumaczeń, logistyki i spedycji, wywozu i utylizacji odpadów, ubezpieczeń, usług fitness, usług IT, edukacji, hotelarstwa, branży metalowej, włókiennictwa, papiernictwa, przetwórstwa tworzyw sztucznych ${ }^{10}$. Jak widać, wiele $\mathrm{z}$ branż przyszłości województwa łódzkiego pokrywa się z listą opracowaną w Foresighcie kadr nowoczesnej gospodarki.

RORP w Łodzi przeprowadziło także analizę ofert pracy publikowanych w prasie i Internecie, na podstawie której opracowano listę najczęściej wskazywanych przez pracodawców wymagań w zakresie umiejętności i kwalifikacji,

${ }^{9}$ Stan i perspektywy rozwoju zasobów ludzkich $w$ branżach przyszłości regionu łódzkiego, Wojewódzki Urząd Pracy w Łodzi, Łódź 2010, s. 6.

${ }^{10}$ Stan i perspektywy rozwoju zasobów ludzkich w branżach przyszłości regionu łódzkiego, Wojewódzki Urząd Pracy w Łodzi, Łódź 2010, s. 9-12. 
jakie powinni posiadać kandydaci do pracy. Następnie określono profil najczęściej poszukiwanego pracownika $\mathrm{w}$ województwie łódzkim. Na profil ten składa się: wykształcenie wyższe lub średnie (przy widocznym spadku etosu wykształcenia wyższego), doświadczenie w branży na podobnym stanowisku, znajomość języka angielskiego, umiejętności komunikacyjne oraz prawo jazdy. Bardziej szczegółowa analiza wykazała, że pracodawcy województwa łódzkiego u kandydatów do pracy poszukują takich umiejętności i cech jak: motywacja i zaangażowanie, zdolności organizacyjne, samodzielność, umiejętności pracy w zespole, umiejętności obsługi komputera ${ }^{11}$.

Równocześnie wyniki analiz wskazują, iż w województwie łódzkim mamy do czynienia $\mathrm{z}$ istotnym niedopasowaniem kapitału ludzkiego do potrzeb zgłaszanych przez pracodawców. Jest to szczególnie widoczne na etapie rekrutacji nowych pracowników. $Z$ badania pracodawców przeprowadzonego w projekcie Bilans Kapitału Ludzkiego wynika, że pracodawcy poszukujący nowych pracowników zgłaszają problemy ze znalezieniem odpowiednich kandydatów do pracy (na 166 poszukujących na takie problemy wskazały 123 osoby, czyli $74,3 \%$ ). Z tej grupy aż 95 respondentów stwierdziło, że mimo iż kandydaci się zgłosili, nie spełniali oczekiwań pracodawcy. Wśród głównych powodów wymieniono brak umiejętności i kompetencji (69 wskazań), brak uprawnień (5 wskazań), brak doświadczenia (24 wskazań), brak motywacji do pracy (10 wskazań), czyli różne komponenty kapitału ludzkiego ${ }^{12}$.

Również wyniki monitoringu zawodów deficytowych i nadwyżkowych (MZDiN) prowadzonego przez publiczne służby zatrudnienia wskazuja, że na rynku pracy województwa łódzkiego występuje nierównowaga w wymiarze kwalifikacyjno-zawodowym między podażową a popytową stroną rynku pracy. W ramach MZDiN, na podstawie liczby zarejestrowanych bezrobotnych i liczby wolnych miejsc pracy i miejsc aktywizacji zawodowej, zgłoszonych przez pracodawców do urzędów pracy (według sekcji PKD), wyznacza się wskaźnik intensywności nadwyżki (deficytu). Wartość wskaźnika poniżej 0,9 oznacza nadwyżkę siły roboczej (więcej bezrobotnych niż zgłoszonych ofert pracy), w przedziale $<0,9 ; 1,1>$ - równowagę, a powyżej 1,1 - deficyt zasobów siły roboczej $\mathrm{w}$ danym zawodzie lub sektorze gospodarki.

Z analizy danych za 2007 r. i 2010 r. wynika, że skala nadwyżki siły roboczej wzrosła - zarówno na poziomie ogólnym jak i w poszczególnych sektorach i sekcjach PKD (Tabela 3).

${ }^{11}$ Poszukiwany pracownik $w$ świetle ofert pracy publikowanych $w$ prasie $i$ Internecie, Wojewódzki Urząd Pracy w Łodzi, Łódź 2010.

${ }^{12}$ Wyniki pochodzą z analizy danych zawartych w bazie SPSS na stronie internetowej projektu Bilans Kapitału Ludzkiego (http://bkl.parp.gov.pl/bazy-danych/; Dostęp: 25.01.2012 r.). 
134 Adaptacja systemów kształcenia zawodowego...

Tabela 3. Wskaźnik intensywności nadwyżki (deficytu) siły roboczej według sektorów ekonomicznych i sekcji PKD w 2007 r. i 2010 r.

\begin{tabular}{|c|c|c|c|}
\hline Wyszczególnienie & 2007 & Wyszczególnienie & 2010 \\
\hline 1 & 2 & 3 & 4 \\
\hline Ogólem & 1,0 & Ogólem & 0,6 \\
\hline $\begin{array}{l}\text { zogólem wedlug sektorów ekono- } \\
\text { micznych: }\end{array}$ & & $\begin{array}{l}\text { z ogólem wedlug sektorów ekonomicz- } \\
\text { nych: }\end{array}$ & \\
\hline rolniczy & 0,4 & rolniczy & 0,4 \\
\hline przemysłowy & 0,8 & przemysłowy & 0,4 \\
\hline usługowy & 1,0 & usługowy & 0,7 \\
\hline zogótem wedtug sekcji PKD 2004: & & z ogótem wedtug sekcji PKD 2007: & \\
\hline Rolnictwo, łowiectwo, leśnictwo & 0,4 & $\begin{array}{l}\text { Rolnictwo, leśnictwo, łowiectwo i rybac- } \\
\text { two }\end{array}$ & 0,4 \\
\hline Rybactwo & 0,0 & Górnictwo i wydobywanie & 0,5 \\
\hline Górnictwo & 0,5 & - & - \\
\hline Przetwórstwo przemysłowe & 0,8 & Przetwórstwo przemysłowe & 0,3 \\
\hline $\begin{array}{l}\text { Wytwarzanie i zaopatrywanie w ener- } \\
\text { gię elektryczną, gaz, wodę }\end{array}$ & 0,7 & $\begin{array}{l}\text { Wytwarzanie i zaopatrywanie w energię } \\
\text { elektryczną, gaz, parę wodna, gorącą } \\
\text { wodę i powietrze do układów klimatyza- } \\
\text { cyjnych }\end{array}$ & 0,6 \\
\hline- & - & $\begin{array}{l}\text { Dostawa wody; gospodarowanie ściekami } \\
\text { i odpadami oraz działalność związana z } \\
\text { rekultywacją }\end{array}$ & 0,8 \\
\hline Budownictwo & 1,1 & Budownictwo & 0,5 \\
\hline $\begin{array}{l}\text { Handel hurtowy i detaliczny; naprawy } \\
\text { pojazdów samochodowych, motocykli } \\
\text { oraz artykułów użytku osobistego i } \\
\text { domowego }\end{array}$ & 0,9 & $\begin{array}{l}\text { Handel hurtowy i detaliczny; naprawa } \\
\text { pojazdów samochodowych, włączając } \\
\text { motocykle }\end{array}$ & 0,5 \\
\hline Hotele i restauracje & 1,1 & $\begin{array}{l}\text { Działalność związana z zakwaterowaniem } \\
\text { i usługami gastronomicznymi }\end{array}$ & 0,5 \\
\hline $\begin{array}{l}\text { Transport, gospodarka magazynowa i } \\
\text { łączność }\end{array}$ & 1,1 & Transport i gospodarka magazynowa & 0,5 \\
\hline- & - & Informacja i komunikacja & 0,7 \\
\hline Pośrednictwo finansowe & 1,5 & Działalność finansowa i ubezpieczeniowa & 0,9 \\
\hline $\begin{array}{l}\text { Obsługa nieruchomości, wynajem i } \\
\text { usługi związane z prowadzeniem dzia- } \\
\text { łalności gospodarczej }\end{array}$ & 0,9 & $\begin{array}{l}\text { Działalność związana z obsługą rynku } \\
\text { nieruchomości }\end{array}$ & 0,7 \\
\hline- & - & $\begin{array}{l}\text { Działalność profesjonalna, naukowa i } \\
\text { techniczna }\end{array}$ & 0,8 \\
\hline- & - & $\begin{array}{l}\text { Działalność w zakresie usług administro- } \\
\text { wania i działalność wspierająca }\end{array}$ & 0,6 \\
\hline $\begin{array}{l}\text { Administracja publiczna i obrona } \\
\text { narodowa, obowiązkowe ubezpiecze- } \\
\text { nia społeczne i powszechne ubezpie- } \\
\text { czenie zdrowotne }\end{array}$ & 1,6 & $\begin{array}{l}\text { Administracja publiczna i obrona narodo- } \\
\text { wa; obowiązkowe zabezpieczenia spo- } \\
\text { łeczne }\end{array}$ & 1,3 \\
\hline
\end{tabular}


Kapitał ludzki w regionie łódzkim z perspektywy przedsiębiorstw... 135

Tabela 3 (cd.)

\begin{tabular}{|c|c|c|c|}
\hline 1 & 2 & 3 & 4 \\
\hline Edukacja & 1,2 & Edukacja & 0,9 \\
\hline Ochrona zdrowia i pomoc społeczna & 1,1 & Opieka zdrowotna i pomoc społeczna & 1,0 \\
\hline $\begin{array}{l}\text { Działalność usługowa, komunalna, } \\
\text { społeczna i indywidualna }\end{array}$ & 0,8 & $\begin{array}{l}\text { Działalność związana z kultura, rozrywką } \\
\text { i rekreacją }\end{array}$ & 1,0 \\
\hline- & - & Pozostała działalność usługowa & 0,3 \\
\hline $\begin{array}{l}\text { Gospodarstwa domowe zatrudniające } \\
\text { pracowników }\end{array}$ & 1,2 & $\begin{array}{l}\text { Gospodarstwa domowe zatrudniające } \\
\text { pracowników; gospodarstwa domowe } \\
\text { produkujące wyroby i świadczące usługi } \\
\text { na własne potrzeby }\end{array}$ & 0,6 \\
\hline Organizacje i zespoły eksterytorialne & 0,0 & Organizacje i zespoły eksterytorialne & 0,7 \\
\hline \multicolumn{4}{|l|}{$\overline{\text { Nadwyżka }}$} \\
\hline \multicolumn{4}{|l|}{ Równowaga } \\
\hline Deficyt & & & \\
\hline
\end{tabular}

Źródło: Nadwyżka i niedobór siły roboczej według sektorów ekonomicznych i sekcji Polskiej Klasyfikacji Działalności (PKD). Raport za 2007 rok, Ministerstwo Pracy i Polityki Społecznej, Warszawa 2008; Nadwyżka i niedobór siły roboczej według sektorów ekonomicznych i sekcji Polskiej Klasyfikacji Działalności (PKD). Raport za 2010 rok, Ministerstwo Pracy i Polityki Społecznej, Warszawa 2011.

Na poziomie sektorów, w 2007 r. jedynie w usługach sytuacja była zrównoważona - w 2010 r. już we wszystkich sektorach zanotowano nadwyżkę. Niestety dokładne porównanie sytuacji na poziomie sekcji PKD, między 2007 a 2010 rokiem nie jest możliwe ze względu na zmianę klasyfikacji, niemniej na podstawie dostępnych danych można zauważyć, że w 2007 r. deficyt zasobów siły roboczej i równowaga występowały w większej liczbie sekcji niż w 2010 r. W 2010 r. deficyt zanotowano jedynie w sekcji: administracja publiczna. Te zmiany wskazują, że przy wzroście bezrobocia wzrosła również nierównowaga łódzkiego rynku pracy w wymiarze kwalifikacyjno-zawodowym - coraz więcej osób bezrobotnych dysponuje kapitałem ludzkim, który jest niedopasowany do potrzeb zgłaszanych przez pracodawców ${ }^{13}$.

Nowoczesne rynki pracy charakteryzują się zmniejszeniem zapotrzebowania na pracę standardową przy wzroście zainteresowania przedsiębiorstw nietypowymi formami zatrudnienia ${ }^{14}$ i organizacji pracy; zwiększeniem zapotrzebowa-

${ }^{13}$ Szczegółową analizę nierównowagi rynku pracy województwa łódzkiego w przekroju zawodów na podstawie monitoringu zawodów deficytowych i nadwyżkowych można znaleźć m.in. w: A. Rogut, Niedopasowania na rynku pracy $w$ województwie tódzkim $w$ zakresie zawodów, Raport opracowany w projekcie „Kapitał ludzki i społeczny jako czynniki rozwoju regionu łódzkiego, http://www.kls.uni.lodz.pl/wyniki-badan/.

${ }^{14}$ Pojęcie zatrudnienia nietypowego stosuje się umownie do określenia zatrudnienia w innej formie niż tradycyjna (typowa, standardowa), za którą uważa się świadczenie pracy: na podstawie umowy o pracę na czas nieokreślony, w pełnym wymiarze czasu pracy, pod stałym nadzorem 
nia na wiedzę, umiejętności i kwalifikacje zawodowe; wzrostem popytu na pracę w sektorze usług wynikającym z procesów serwicyzacji wysoko rozwiniętych gospodarek, szczególnie w dużych ośrodkach miejskich. Pojawia się pytanie, czy rynek pracy województwa łódzkiego można nazwać rynkiem nowoczesnym?

Próbując odpowiedzieć na to pytanie, na wstępie należy zaznaczyć, że przestrzenny rozkład popytu na pracę (mierzonego liczbą pracujących w głównym miejscu pracy) wskazuje na dominującą rolę Łodzi, jako centrum regionalnego rynku pracy - w mieście Łódź pracuje około 40\% ogółu pracujących w województwie łódzkim. Pozostałe miasta na obszarze województwa odgrywają mniejszą rolę, pełniąc funkcje centrów lokalnych rynków pracy ${ }^{15}$.

Statystyka publiczna niestety nie dysponuje wieloma informacjami na temat wykorzystania nietypowych form zatrudnienia. Dostępne w Banku Danych Lokalnych Głównego Urzędu Statystycznego dane na temat zatrudnienia w pełnym i niepełnym wymiarze czasu pracy wskazują, że w porównaniu do 2000 r., w 2010 r. zmniejszył się odsetek pracujących w niepełnym wymiarze czasu pracy, i to zarówno wśród kobiet, jak i mężczyzn (ogółem o 3 p. p., mężczyzn o 5 p.p, a kobiet o 2 p. p.). $Z$ danych dostępnych w bazie Eurostatu wynika też, że w województwie łódzkim w latach 2001-2010 zmniejszał się udział osób samozatrudnionych w ogólnej liczbie pracujących z 24\% do 19\%. Jeśli te dwie kategorie potraktować jako aproksymantę zmian $\mathrm{w}$ strukturze popytu na pracę w obrębie nietypowych form zatrudnienia, oznaczałoby to, iż rynek pracy województwa łódzkiego ewoluuje w kierunku przeciwnym do światowych trendów.

Natomiast niewątpliwie w regionie łódzkim widoczny jest wzrost zapotrzebowania na kadry dysponujące wysokim formalnym poziomem wykształcenia porównanie struktury pracujących, według poziomu wykształcenia, między 2000 r. a 2010 r. wskazuje jednoznacznie na wzrost udziału w zasobie pracujących osób z wykształceniem wyższym (z 14,6\% do 25,9\%) i średnim ogólnokształcącym (z $8,2 \% \%$ do $10,5 \%$ ). Zmalał natomiast udział pracujących z wykształceniem policealnym i średnim zawodowym (z 31,3\% do 27,6\%), zasadniczym

pracodawcy, wykonywane w siedzibie pracodawcy, w określonych, stałych godzinach. Pozostałe formy zatrudnienia określane są jako nietypowe lub szczególne. Dotyczy to sytuacji, w której jedna lub więcej z wszystkich wymienionych powyżej cech typowego zatrudnienia nie zachodzi. Do podstawowych rodzajów nietypowego zatrudnienia zalicza się: zatrudnienie $\mathrm{w}$ niepełnym wymiarze czasu, zatrudnienie terminowe (na czas określony), samozatrudnienie, zatrudnienie tymczasowe (wypożyczanie pracowników) i telepraca.

${ }^{15}$ Równocześnie z badań przeprowadzonych w projekcie „Kapitał ludzki i społeczny jako czynniki rozwoju regionu łódzkiego" wynika, że pozycja Łodzi pod względem indywidualnych zasobów kapitału ludzkiego i społecznego jest relatywnie słaba w porównaniu do innych ośrodków województwa łódzkiego - por. Kapitat ludzki i społeczny regionu tódzkiego - Raport z badań ankietowych na reprezentatywnej próbie mieszkańców województwa tódzkiego, http://www.kls.uni.lodz.pl/wyniki-badan/. 
zawodowym (z $30,6 \%$ do $26,8 \%$ ) oraz gimnazjalnym i poniżej (z $15,2 \%$ do $9,1 \%)^{16}$.

Proces serwicyzacji w województwie łódzkim postępuje wolniej niż w kraju - w odróżnieniu od tendencji krajowych w Łódzkiem obserwujemy wzrost udziału pracujących $\mathrm{w}$ przemyśle. Jest to spowodowane lokalizacją dużych inwestycji przemysłowych - szczególnie w Łódzkiej Specjalnej Strefie Ekonomicznej (ŁSSE). Firmy w ŁSSE to firmy średnie i duże, które w pierwszych latach pogarszającej się koniunktury były mniej wrażliwe na skutki światowego kryzysu, co częściowo wyjaśnia wzrost $\mathrm{w}$ regionie udziału pracujących $\mathrm{w}$ przemyśle w 2009 r. Poza Łodzią tylko dwa miasta na prawach powiatu - Piotrków Trybunalski i Skierniewice charakteryzują się dużym stopniem serwicyzacji (odpowiednio 64\% i 61\% pracujących w usługach), przy czym w przypadku Skierniewic zauważalny jest $\mathrm{w}$ ostatnich latach stopniowy proces uprzemysłowienia, a nie serwicyzacji.

W perspektywie 2020 r. należy zakładać, że zachodzące procesy serwicyzacji będą prowadziły do wzrostu udziału pracujących w usługach kosztem rolnictwa i przemysłu, chociaż nie będą to zmiany rewolucyjne, a poszczególne powiaty zachowają swój dotychczasowy charakter. Należy więc przyjąć, iż najbardziej nowoczesna struktura zatrudnienia nadal będzie charakterystyczna dla miast na prawach powiatu, które będą pełniły funkcję lokalnych/regionalnych biegunów wzrostu ${ }^{17}$.

Pracownik na nowoczesnym rynku pracy musi dysponować zestawem umiejętności miękkich, bez których utrzymanie pracy będzie niezwykle trudne. Eksperci rynku pracy podkreślają że pracę otrzymuje się w 70\% dzięki wiedzy fachowej i w 30\% dzięki kompetencjom społecznym, traci się zaś w 70\% z braku kompetencji społecznych i w $30 \%$ z braku kwalifikacji merytorycznych ${ }^{18}$. Jest to o tyle istotne, że w nowoczesnej gospodarce pracownik co najmniej kilka razy w życiu będzie zmieniał zawód i w związku z tym będzie musiał dostosować się do potrzeb rynku pracy w wymiarze kwalifikacyjno-zawodowym ${ }^{19}$. Mimo, że rynek pracy województwa łódzkiego nie spełnia obecnie kryteriów pozwalających

${ }^{16}$ E. Kryńska, I. Kukulak-Dolata, Ł. Arendt, Analiza regionalnego rynku pracy-metropolitarnego, subregionalnych, na potrzeby aktualizacji „,Strategii Rozwoju Województwa Lódzkiego na lata 2007-2020”, Łódź 2011 (maszynopis), s. 8.

${ }^{17}$ E. Kryńska, I. Kukulak-Dolata, Ł. Arendt, Analiza regionalnego rynku pracy - metropolitarnego, subregionalnych, na potrzeby aktualizacji „Strategii Rozwoju Województwa Łódzkiego na lata 2007-2020", Łódź 2011 (maszynopis), 40-41.

${ }^{18}$ M. Juchnowicz, Polityka edukacyjna wobec potrzeb rynku pracy [w:] Ksztaltowanie postaw przedsiębiorczych a edukacja ekonomiczna, P. Wachowiak, M. Dąbrowski, B. Majewski (red.), Fundacja Promocji i Akredytacji Kierunków Ekonomicznych, Warszawa 2007, s. 40-46.

${ }^{19}$ Matusiak K. B., Arendt Ł., Kadry dla nowoczesnej gospodarki - wyzwania dla systemu edukacji [w:] Kreatywność - Innowacje - Przedsiębiorczość. SOOIPP Annual 2009, Zeszyty Naukowe Uniwersytetu Szczecińskiego, nr 579, Ekonomiczne problemy usług nr 47, Szczecin 2010, s. 29-44. 
zaliczyć go do grupy nowoczesnych rynków pracy, coraz większy nacisk kładziony jest w nim na jakość dostępnego kapitału ludzkiego.

Nie wymaga szczególnego procesu dowodowego stwierdzenie, iż podstawowym narzędziem kreowania kapitału ludzkiego są systemy kształcenia zawodowego, zarówno szkolne, jak i pozaszkolne, wiążące się tak z edukacją formalną, jak i nieformalną ${ }^{20}$. Dalsza część opracowania poświęcona jest identyfikacji zdolności adaptacyjnych systemów kształcenia zawodowego w regionie łódzkim, do wymagań stawianych przez współczesne rynki pracy. Przeprowadzone analizy stały się podstawą sformułowania wniosków i rekomendacji, mających na celu poprawę tejże adaptacyjności, dla umożliwienia właściwego zakresu i kierunków kreacji kapitału ludzkiego w regionie.

\section{Ewolucja czy rewolucja w systemach kształcenia zawodo- wego w regionie łódzkim?}

Na system kształcenia zawodowego składają się dwa komponenty - szkolny, obejmujący określone rodzaje szkół ponadgimnazjalnych oraz pozaszkolny, który stanowi element edukacji ustawicznej w formie kursów, seminariów, staży, praktyk, szkoleń, itp. Szkolne kształcenie zawodowe prowadzone jest przez: specjalne szkoły przysposabiające do pracy, zasadnicze szkoły zawodowe, technika uzupełniające, licea profilowane, technika, szkoły artystyczne II stopnia, szkoły policealne oraz szkoły wyższe (wyższe szkoły zawodowe i uczelnie prowadzące studia licencjackie i inżynierskie) ${ }^{21}$.

\subsection{Główne elementy zmian systemów szkolnego kształcenia zawodowego w regionie łódzkim}

Poziom wykształcenia ludności powyżej 15 roku życia w województwie łódzkim rośnie. Zmiany w strukturze ludności, według wykształcenia, widoczne są przede wszystkim $\mathrm{w}$ grupie osób z wykształceniem wyższym, której udział wzrósł między 2000 r. a 2010 r. niemal dwukrotnie, przy równoczesnym, znaczącym spadku udziału osób z wykształceniem gimnazjalnym i poniżej (Wykres 1).

${ }^{20}$ Zgodnie z klasyfikacją W. Okonia, zob. W. Okoń, Stownik pedagogiczny, Wydawnictwo Naukowe PWN, Warszawa 1992.

${ }^{21}$ J. Boratyński, Szkolnictwo zawodowe i rynek pracy województwa tódzkiego na tle kraju, Księży Młyn Dom Wydawniczy Michał Koliński, Łódź 2009, s. 8-9; Oświata i Wychowanie w roku szkolnym 2010/2011, Główny Urząd Statystyczny, Warszawa 2011, s. 23-31. 
Wykres 1. Struktura ludności województwa łódzkiego (15+) według poziomu wykształcenia w 2000 r. i 2010 r.

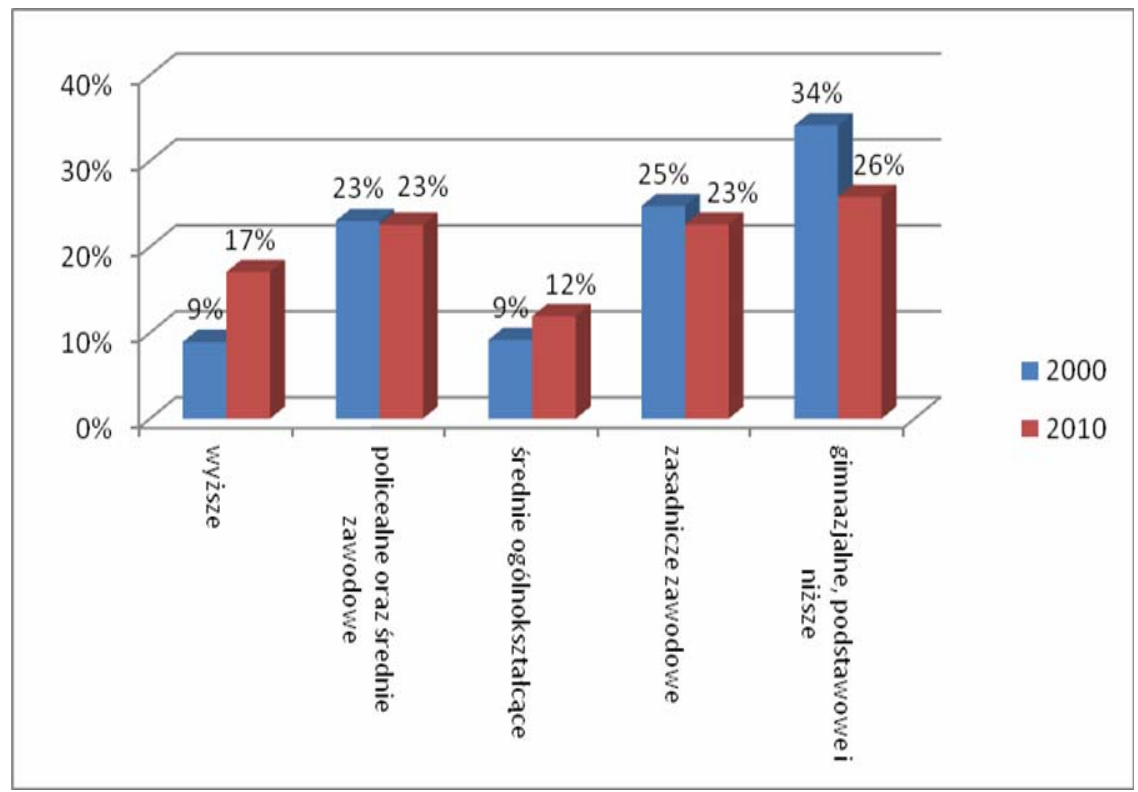

Źródło: obliczenia na podstawie danych GUS (Bank Danych Lokalnych).

Widać więc, że system kształcenia szkolnego, przynajmniej w płaszczyźnie ilościowej, odpowiedział na zapotrzebowanie rynku pracy. Tym niemniej wyniki badań wskazuja, iż kapitał ludzki w regionie nie rozwija się w kierunkach i tempie adekwatnym do potrzeb nowoczesnej gospodarki, a pracodawcy mają istotne problemy z zaspokojeniem potrzeb kadrowych. Przyczyn takiego stanu jest wiele jedną $\mathrm{z}$ nich, która miała znaczący wpływ na zmiany w funkcjonowaniu i znaczeniu szkolnictwa zawodowego w województwie łódzkim były procesy, które miały miejsce na początku okresu transformacji, w obszarze działalności edukacyjnej podmiotów gospodarczych. W okresie tym nastapiła bowiem - po pierwsze - rezygnacja wielu zakładów pracy z kształcenia praktycznego oraz po drugie - rezygnacja zakładów pracy z prowadzenia szkół przyzakładowych. Oba te czynniki spowodowały konieczność zwiększenia liczby uczniów, realizujących programy kształcenia praktycznego w warsztatach szkolnych - co w warunkach słabego wyposażenia tych placówek i przy ogólnych niedoborach finansowych szkół - źle wpłynęło na poziom kształcenia praktycznego.

Najważniejsze zmiany w szkolnictwie zawodowym w województwie łódzkim polegały na ograniczeniu rozmiarów kształcenia w szkołach zawodowych, $\mathrm{z}$ równoczesnym wzrostem odsetka uczących się w liceach ogólnokształcących oraz rezygnacji z wąskich specjalności na rzecz kształcenia szerokoprofilowego. 
Istotną zmianą w systemie szkolnictwa było wprowadzenie szkół nowego typu (najpierw liceum technicznego, potem liceum profilowanego kształcącego w profilach kształcenia ogólnozawodowego) oraz wzbogacenie go i poszerzenie o sieć szkół niepublicznych. W efekcie znacznie zwiększyła się liczba uczniów i absolwentów szkół średnich (zwłaszcza liceów ogólnokształcących) oraz (w szczególnie dużej skali) liczba studentów i absolwentów szkół wyższych. Nastąpiło dość szerokie wprowadzenie przedmiotów humanistycznych do wszelkich szkół zawodowych i przesunięcie wielu form kształcenia zawodowego na poziom pomaturalny. System ten charakteryzuje dążenie do przedłużenia procesu kształcenia i przeniesienia kształcenia zawodowego na późniejsze lata. Takie ograniczenie kształcenia zawodowego może niekorzystnie wpłynąć na konkurencyjność, produktywność i jakość pracy zasobów ludzkich w województwie łódzkim.

W ostatnim okresie nastapiły pozytywne zmiany w regionalnym systemie kształcenia zawodowego, zwłaszcza w zakresie typów szkół ponadgimnazjalnych wybieranych przez uczniów. Traciły mianowicie na znaczeniu licea profilowane, rosła natomiast popularność zasadniczych szkół zawodowych (przy delikatnym spadku zainteresowania w 2010 r.) oraz techników dla młodzieży. Należy domniemywać, iż powodem tych zmian był rosnący popyt na pracowników dysponujących kwalifikacjami i kompetencjami technicznymi. Proces ten świadczy o pewnej elastyczności systemu zawodowej edukacji szkolnej w województwie łódzkim.

Niestety, utrzymuje się tendencja do wypierania kształcenia zawodowego przez kształcenie ogólne na poziomie ponadgimnazjalnym. Liczba uczniów poszczególnych typów szkół maleje, przy czym większe spadki notuje się w przypadku szkół zawodowych (o 11\% w okresie 2007-2010, podczas gdy w przypadku szkół ogólnokształcących spadek wyniósł 7,2\%). Na dodatek dużym problemem jest jakość kształcenia, jaką oferują średnie szkoły zawodowe. Za miarę skuteczności kształcenia w szkołach zawodowych na poziomie średnim można uznać odsetek osób zdających egzamin dojrzałości. Wnioski z analizy w tym zakresie dla województwa łódzkiego są niepokojące, przy czym nie odbiegają (niestety) od sytuacji w Polsce. Po pierwsze, odsetek osób, które zdają maturę był wyższy o 17 p. p. w liceach ogólnokształcących niż średnich szkołach zawodowych, co wskazuje, że jakość kształcenia w tych drugich jest niższa. Po drugie, w latach 2002-2010 przy fluktuacjach odsetka absolwentów średnich szkół zawodowych pozytywnie zweryfikowanych podczas egzaminu dojrzałości, widać tendencję do spadku tegoż odsetka (w 2002 wyniósł 97\%, podczas gdy w 2010 tylko 74\%).

Tymczasem z badań prowadzonych przez RORP w Łodzi wynika, że to właśnie system kształcenia zawodowego na poziomie zarówno średnim, jak i zasadniczym, jest najlepiej oceniany przez pracodawców na tle całego systemu eduka- 
cji. Również absolwenci tych szkół pozytywnie oceniają nabyte w trakcie kształcenia kwalifikacje i umiejętności, co pozwala im czuć się pewnie na rynku pracy ${ }^{22}$.

Ogólnie krytyczna ocena systemu edukacji, pojawiająca się w wypowiedziach pracodawców i osób pracujących, czasami potwierdzana przez przedstawicieli instytucji edukacyjnych, dotyczy czterech głównych zarzutów. Po pierwsze, w procesie kształcenia faworyzowany jest podręcznikowy sposób przekazywania wiedzy, przy niedocenianiu roli zajęć praktycznych, co skutkuje małych udziałem tych drugich $\mathrm{w}$ programach kształcenia. Po drugie, same programy kształcenia nie są aktualizowane i dostosowywane do zachodzących zmian technologicznych, a co za tym idzie - nie odpowiadają również zapotrzebowaniu na kwalifikacje i umiejętności, zgłaszanemu przez pracodawców. Wynika to z dużej instytucjonalnej sztywności i znacznej inercyjności systemu oświaty. Po trzecie, istniejący system w niewystarczającym zakresie kształtuje umiejętności miękkie, podczas gdy umiejętności te odgrywają kluczową rolę w możliwościach adaptacji do wymagań rynku pracy. Pracodawcy oczekiwaliby, aby absolwent kończąc daną szkołę dysponował umiejętnościami miękkimi na poziomie porównywalnym ze stanem opanowania wiedzy teoretycznej. Pracodawcy z województwa łódzkiego dostrzegają też rosnące znaczenie elastyczności pracowników rozumianej jako zdolność do wykonywania obowiązków zawodowych wykraczających poza zakres danego stanowiska pracy - to wskazuje, że zmiany na łódzkim rynku pracy są zbieżne ze światowymi tendencjami. I wreszcie po czwarte, brakuje systemowego rozwiązania dotyczącego oceny predyspozycji zawodowych uczniów na wczesnym etapie kształcenia, co skutkuje przypadkowym wyborem ścieżki kariery zawodowej przez młode osoby.

System kształcenia zawodowego na poziomie wyższym w województwie łódzkim również nie jest oceniany pozytywnie przez aktorów rynku pracy. Szkoły wyższe, mimo większej autonomii w zakresie ustalania programów kształcenia, podobnie jak szkoły niższych szczebli nie są w stanie dostosować treści kształcenia do zapotrzebowania rynku pracy. Wśród przyczyn takiego stanu wskazuje się:

- zbyt słabą współpracę szkół wyższych z pracodawcami (również w zakresie organizacji praktyk czy staży), którzy mają bardzo ograniczony (jeśli jakikolwiek) wpływ na programy kształcenia;

- kierowanie się szkół wyższych, w tworzeniu programów kształcenia czy otwieraniu kierunków studiów, popytem ze strony młodzieży i panująca modac, a nie potrzebami rynku pracy. W rezultacie w 2010 r. najwięcej osób w województwie łódzkim studiowało na kierunkach ekonomia i administracja $(25 \%)$ oraz pedagogicznych (14\% ogółu), gdzie wiadomo, że rynek pracy w tych segmentach jest już nasycony;

${ }^{22}$ Umiejętności zawodowe - teoria a praktyka. Wyniki badań $w$ województwie lódzkim, Wojewódzki Urząd Pracy w Łodzi, Łódź 2010, s. 91. 
- dostosowywanie treści kształcenia do zasobów kadrowych, jakimi dysponują uczelnie.

Próby nawiązania bliższej współpracy między szkołami wyższymi a pracodawcami poprzez powoływanie do życia Rad Biznesu - ciał doradczych działających na poziomie szkoły, czy wydziału, jak na razie nie przynoszą oczekiwanych rezultatów.

W wyniku istniejącego niedostosowania systemu kształcenia zawodowego na poziomie wyższym do potrzeb rynku pracy w województwie łódzkim, jedynie (lub aż) niecałe $60 \%$ absolwentów szkół wyższych podejmuje pierwszą pracę zgodną z wybranym kierunkiem edukacji ${ }^{23}$.

Na regionalnym rynku pracy województwa łódzkiego, wiedza i umiejętności zawodowe są towarem w dalszym ciagu deficytowym. Pracodawcy uskarżają się na małe umiejętności praktyczne i brak doświadczenia zawodowego kandydatów do pracy, a także, co należy wyraźnie podkreślić - na brak na lokalnych rynkach pracy absolwentów odpowiednich kierunków kształcenia ${ }^{24}$.

Innym istotnym problemem w województwie łódzkim jest również nierównomierny rozwój i dostępność instytucji kształcenia zawodowego - z tego punktu widzenia regionalny rynek pracy jest spolaryzowany. Daje się wyodrębnić obszary uprzywilejowane pod tym względem, gdzie nasycenie instytucjami edukacyjnymi jest wysokie - dotyczy to Łodzi i innych dużych miast regionu oraz obszary, gdzie dostępność ta jest znikoma - dotyczy to głównie terenów wiejskich oddalonych od dużych miast. Przed mieszkańcami tych drugich obszarów stoją bariery inwestowania w kapitał ludzki. Ich pokonanie wymaga wysiłku oraz poniesienia nakładów, co stawia ich w relatywnie gorszej sytuacji i wymaga zdecydowanych działań na rzecz wyrównania szans na rynku pracy.

Podsumowując tę część opracowania, należy stwierdzić, iż z punktu widzenia łódzkiego rynku pracy, do niedostatków systemu szkolnego kształcenia zawodowego należy zaliczyć:

- nierówność w dostępie (gorszy dostęp do edukacji mają młodzi ludzie pochodzący ze wsi lub małych miast, przynależni do słabiej wykształconej grupy społecznej oraz niepełnosprawni);

- ograniczanie praktycznego kształcenia zawodowego i praktyk zawodowych na rzecz kształcenia ogólnego (prowadzi to do niedoboru robotników wykwalifikowanych);

${ }^{23}$ Umiejętności zawodowe - teoria a praktyka. Wyniki badań w województwie łódzkim, Wojewódzki Urząd Pracy w Łodzi, Łódź 2010, s. 77.

${ }^{24}$ J. Witkowski (red.), Rynek pracy w województwie łódzkim Specyfika i uwarunkowania. Raport końcowy z realizacji projektu DIAGNOZA ZAWODÓW, ASM Centrum Badań i Analiz Rynku, Instytut Pracy i Spraw Socjalnych, 2007, por. też Migracja pracowników - szansa czy zagrożenie? Badanie - edycja 2008 rok. Raport KPMG, KPMG, PKPP Lewiatan, 2008, bądź kwartalne raporty przygotowywane przez Manpower. 
- brak dostosowań kierunków i programów kształcenia do perspektywicznych potrzeb rynku pracy (ciągle nie stosuje się szczególnej metodologii prognozowania i zapotrzebowania na prace według kwalifikacji, a badania tego ty$\mathrm{pu}$, jakkolwiek prowadzone $\mathrm{w}$ wielu instytucjach, nie mają jeszcze charakteru systemowego i długookresowego);

- brak sprawnych mechanizmów koordynacji bieżącej systemu edukacji i potrzeb rynku pracy.

\subsection{Wsparcie i dostosowanie kształcenia zawodowego do nowych trendów rynku pracy - rola instytucji i aktorów rynku pracy}

Biorąc pod uwage tempo zmian technologicznych oraz procesy demograficzne, system kształcenia ustawicznego ma do odegrania istotną rolę w równoważeniu rynku pracy w wymiarze kwalifikacyjno-zawodowym, co znalazło swoje odzwierciedlenie w koncepcji flexicurity. Dokształcanie zawodowe poprzez kształcenie ustawiczne jest niezbędnym czynnikiem stymulującym mobilność pracowniczą, poprzez zwiększanie zdolności i możliwości pracobiorców dostosowania się do jakościowych zmian popytu na pracę, we względnie krótkich okresach.

Jednak jak pokazują dane, skłonność polskich zasobów pracy do uczestniczenia w kształceniu ustawicznym jest niższa niż w krajach wysoko rozwiniętych. Na dodatek, na tle kraju województwo łódzkie wypada co najwyżej średnio, notując od 2000 r. niższe wskaźniki w tym obszarze niż średnio dla Polski (Wykres 2). Jedynie w latach 2004-2005 wskaźnik dla województwa łódzkiego był porównywalny z jego wartością krajową, podczas gdy w latach 2007-2009 nastapił znaczący jego spadek.

Zasadnicze znaczenie dla prawidłowego funkcjonowania pozaszkolnego systemu kształcenia zawodowego ma działalność publicznych służb zatrudnienia (Schemat 1), które udzielają wsparcia w zakresie podnoszenia kompetencji i kwalifikacji, w ramach usług szkoleniowych oraz instrumentów i programów służących podnoszeniu kompetencji. W ramach usług szkoleniowych wsparcie obejmuje:

- skierowanie na szkolenie w formie kursowej;

- finansowanie studiów podyplomowych;

- udzielanie pożyczek na sfinansowanie kosztów szkolenia ${ }^{25}$;

- finansowanie kosztów egzaminów lub uzyskania licencji.

${ }^{25}$ Ten rodzaj wsparcia praktycznie pozostaje pustym zapisem w Ustawie o promocji zatrudnienia i instytucjach rynku pracy - w 2009 r. w całej Polsce udzielono tylko 37 pożyczek, z czego na województwo łódzkie przypadły dwie, udzielone przez Powiatowy Urząd Pracy w Łęczycy. 
144 Adaptacja systemów kształcenia zawodowego...

Wykres 2. Kształcenie ustawiczne osób w wieku 25-64 lata

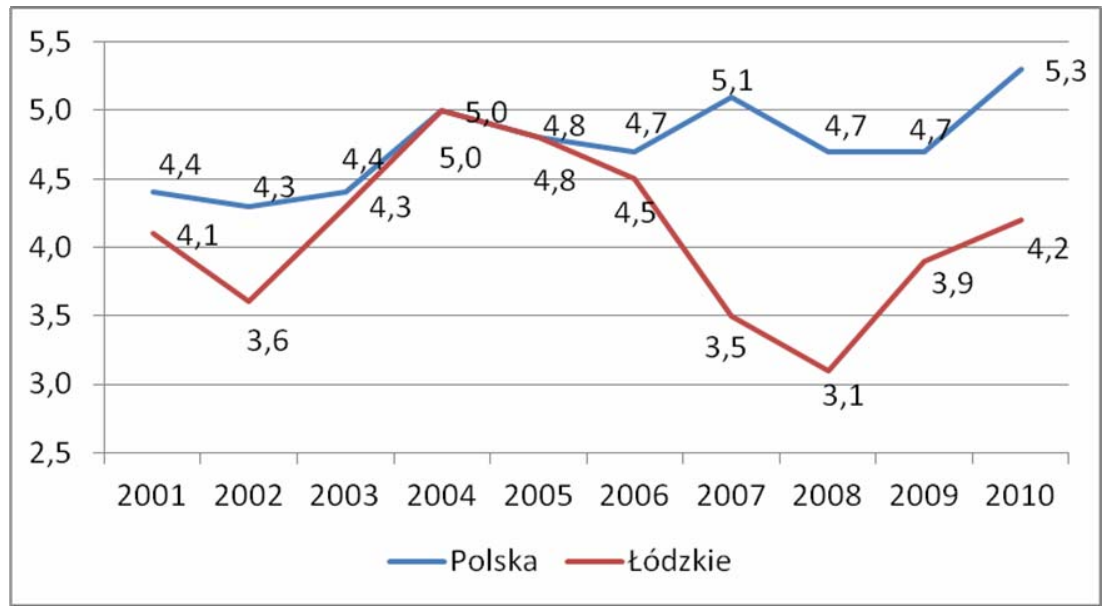

Źródło: dane GUS (Bank Danych Lokalnych)

Instrumentami/programami służącymi podnoszeniu kompetencji są natomiast:

- staż;

- przygotowanie zawodowe dorosłych;

- stypendium na kontynuowanie nauki.

Jak wynika z badań, zarówno wielkość nakładów na szkolenia bezrobotnych i poszukujących pracy, jak też ich efektywność w województwie łódzkim, nie są satysfakcjonujące ${ }^{26}$. Nieco inne wnioski dotyczą staży i przygotowania do zawodu w miejscu pracy. Mimo wzrostu liczby bezrobotnych kierowanych w poszczególnych latach na szkolenia, wydatki na ten cel nie przekroczyły dotychczas $10 \%$ ogółu środków wydatkowanych na aktywne formy przeciwdziałania bezrobociu (Tabela 4). Równocześnie z roku na rok rósł koszt ponownego zatrudnienia ${ }^{27}$ przy malejącej efektywności zatrudnieniowej ${ }^{28}$ szkoleń.

${ }^{26}$ Zob. E. Kryńska, Rekomendacje dotyczace polityki rynku pracy, Księży Młyn Dom Wydawniczy Michał Koliński, Łódź 2009.

${ }^{27}$ Koszt ponownego zatrudnienia, określany również efektywnością kosztową, definiowany jest jako stosunek kwoty poniesionych w danym roku kalendarzowym wydatków (kasowo) na określoną formę aktywizacji do liczby osób, które po zakończeniu udziału w danym roku kalendarzowym w tej formie aktywizacji uzyskały w okresie do 3 miesięcy zatrudnienie.

${ }^{28}$ Efektywność zatrudnieniowa (inaczej wskaźnik ponownego zatrudnienia) definiowana jest jako stosunek liczby osób, które po zakończeniu udziału w określonej formie aktywizacji w danym roku kalendarzowym uzyskały w okresie do 3 miesięcy zatrudnienie, tj. wyrejestrowały się z powiatowego urzędu pracy lub jeżeli w okresie do 3 miesięcy od czasu zakończenia udziału w programach nie zarejestrowały się w powiatowym urzędzie pracy, do liczby osób, które w danym roku kalendarzowym zakończyły udział w danej formie aktywizacji. 
Kapitał ludzki w regionie łódzkim z perspektywy przedsiębiorstw... 145

Tabela 4. Charakterystyki wybranych aktywnych form przeciwdziałania bezrobociu

\begin{tabular}{|c|l|c|c|c|}
\hline \multirow{2}{*}{ Rok } & \multicolumn{1}{|c|}{ Wyszzczególnienie } & \multicolumn{3}{|c|}{ Aktywna forma przeciwdziałania bezrobociu } \\
\cline { 3 - 5 } & & szkolenia & staże & $\begin{array}{c}\text { przygotowanie do zawodu } \\
\text { w miejscu pracy }\end{array}$ \\
\hline \multirow{5}{*}{2007} & Liczba osób aktywizowanych & 11769 & 12009 & 3781 \\
\cline { 2 - 5 } & Efektywność zatrudnieniowa & $42,7 \%$ & $60,5 \%$ & $54,1 \%$ \\
\cline { 2 - 5 } & Efektywność kosztowa & 2834 & 6106 & 6348 \\
\cline { 2 - 5 } & Udział w wydatkach ogółem & $7,9 \%$ & $25,5 \%$ & $6,8 \%$ \\
\hline \multirow{4}{*}{2008} & Liczba osób aktywizowanych & 11890 & 11649 & 4113 \\
\cline { 2 - 5 } & Efektywność zatrudnieniowa & $36,4 \%$ & $63,3 \%$ & $57,1 \%$ \\
\cline { 2 - 5 } & Efektywność kosztowa & 4075 & 9461 & 9553 \\
\cline { 2 - 5 } & Udział w wydatkach ogółem & $7,5 \%$ & $26,6 \%$ & $8,2 \%$ \\
\hline \multirow{4}{*}{2009} & Liczba osób aktywizowanych & 12372 & 16948 & 300 \\
\cline { 2 - 5 } & Efektywność zatrudnieniowa & $30,5 \%$ & $53,2 \%$ & $60,5 \%$ \\
\cline { 2 - 5 } & Efektywność kosztowa & 6627 & 11323 & 8241 \\
\cline { 2 - 5 } & Udział w wydatkach ogółem & $8,5 \%$ & $30,2 \%$ & $2,0 \%$ \\
\hline \multirow{3}{*}{2010} & Liczba osób aktywizowanych & 14192 & 19758 & - \\
\cline { 2 - 5 } & Efektywność zatrudnieniowa & $32,4 \%$ & $51,3 \%$ & - \\
\cline { 2 - 5 } & Efektywność kosztowa & 7640 & 13408 & - \\
\cline { 2 - 5 } & Udział w wydatkach ogółem & $9,5 \%$ & $32,2 \%$ & - \\
\hline
\end{tabular}

Źródło: opracowanie na podstawie: Efektywność podstawowych form aktywizacji zawodowej realizowanych w ramach programów na rzecz promocji zatrudnienia, łagodzenia skutków bezrobocia i aktywizacji zawodowej w 2010 roku, Ministerstwo Pracy i Polityki Społecznej, Warszawa 2011; Efektywność podstawowych form aktywizacji zawodowej realizowanych w ramach programów na rzecz promocji zatrudnienia, łagodzenia skutków bezrobocia i aktywizacji zawodowej w 2009 roku, Ministerstwo Pracy i Polityki Społecznej, Warszawa 2010; Efektywność podstawowych form promocji zatrudnienia i aktywizacji zawodowej bezrobotnych finansowanych z Funduszu Pracy w 2008 roku, Ministerstwo Pracy i Polityki Społecznej, Warszawa 2009; Efektywność podstawowych form promocji zatrudnienia i aktywizacji zawodowej bezrobotnych finansowanych z Funduszu Pracy w 2007 r., Ministerstwo Pracy i Polityki Społecznej, Warszawa 2008.

Zamiast przygotowania do zawodu w miejscu pracy, w 2010 r. wprowadzono przygotowanie zawodowe dorosłych, które nie cieszy się dużym zainteresowaniem. Do 2009 r. przygotowanie do zawodu w miejscu pracy nie było zbyt popularnym instrumentem wykorzystywanym w województwie łódzkim, chociaż charakteryzował się on relatywnie wysoką efektywnością zatrudnieniową.

W przypadku staży mieliśmy natomiast do czynienia ze wzrostem wydatków na ten cel w wydatkach ogółem (do poziomu około 1/3 ogółu wydatków), przy rosnącym koszcie ponownego zatrudnienia i malejącej od 2009 r. efektywności zatrudnieniowej. Warto zauważyć, że staże charakteryzują się znacznie wyższą efektywnością zatrudnieniową niż szkolenia, mimo że część pracodawców traktuje staże wyłącznie jako formę dotowanego zatrudnienia. Okazuje się 
jednak, że zdobycie praktycznego doświadczenia podczas stażu daje większe szanse na zatrudnienie niż ukończenie szkolenia, które nie zawsze jest dobierane z uwzględnieniem potrzeb rynku pracy, jak i predyspozycji osób bezrobotnych.

Problem ten jest szczególnie widoczny w przypadku organizacji szkoleń współfinansowanych ze środków Europejskiego Funduszu Społecznego, gdzie środki przyznawane są w trybie konkursowym. Przedstawiciele instytucji pośredniczącej sami przyznają, że czasami muszą, z przyczyn formalnych, przyznać środki na realizację szkoleń, których tematyka nie odpowiada zapotrzebowaniu lokalnych czy regionalnego rynku pracy województwa łódzkiego. Lepsza sytuacja występuje w przypadku szkoleń kontraktowanych bezpośrednio przez publiczne służby zatrudnienia, co jest widoczne w instytucjach szkoleniowych i wpisach do Rejestru Instytucji Szkoleniowych prowadzonych przez Wojewódzki Urząd Pracy ${ }^{29}$.

Charakterystyczne dla polskiej polityki rynku pracy jest przeznaczanie zbyt dużej puli środków w strukturze wydatków, na aktywną politykę rynku pracy przez publiczne służby zatrudnienia, na instrumenty zorientowane popytowo, podczas gdy zgodnie z zaleceniami Komisji Europejskiej subwencjonowanie zatrudnienia bezrobotnych powinno być ograniczane. Stąd jednym z zaleceń sformułowanych $w$ ramach projektu „Flexicurity $w$ Polsce. Diagnoza i rekomendacje" było zwiększenie udziału wydatków na instrumenty zorientowane podażowo (czyli te, które wspierają rozwój kapitału ludzkiego - szkolenia, staże i przygotowanie zawodowe dorosłych) do około $70 \%$ do 2012 r. $^{30}$. W 2010 r. województwo łódzkie było o 9 p. p. poniżej tego poziomu, a biorąc pod uwagę skalę zróżnicowania wewnątrzregionalnego, dojście do 2012 r. do rekomendowanej struktury alokacji wydaje się mało prawdopodobne.

Nawiązując do skutków światowego kryzysu finansowego, dodać trzeba, iż obniżenie środków Funduszu Pracy na programy przeciwdziałania bezrobociu, będące efektem działań służących równoważeniu finansów publicznych, które ma miejsce od 2011 r., nie sprzyja wykorzystaniu aktywnej polityki rynku pracy, do kreacji kapitału ludzkiego $\mathrm{w}$ regionie łódzkim.

Dla rozwoju kapitału ludzkiego, zgodnego z zapotrzebowaniem regionalnego łódzkiego rynku pracy, istotne znaczenie mają również działania podejmowane przez Wojewódzki Urząd Pracy w Łodzi i funkcjonujące w jego strukturach Regionalne Obserwatorium Rynku Pracy w Lodzi (Schemat 1). Tak jak powiatowe urzędy pracy, w ramach usług i instrumentów rynku pracy, realizują zadania operacyjne świadcząc bezpośrednie wsparcie osobom bezrobotnym i poszukującym pracy, tak zadaniem Wojewódzkiego Urzędu Pracy jest kreowa-

${ }^{29}$ W końcu stycznia 2012 r. w Rejestrze Instytucji Szkoleniowych było zarejestrowanych 582 instytucje z województwa łódzkiego.

30 E. Kryńska (red.), Flexicurity w Polsce. Diagnoza i rekomendacje, Ministerstwo Pracy i Polityki Społecznej, Departament Rynku Pracy, Warszawa 2009, s. 202-203. 
nie regionalnej polityki rynku pracy, w tym rozwoju zasobów ludzkich, między innymi poprzez prowadzenie badań i analiz popytu na kwalifikacje i umiejętności. Standardowym instrumentem wykorzystywanym od lat do tego celu jest monitoring zawodów deficytowych i nadwyżkowych (prowadzony przez powiatowe i wojewódzkie urzędy pracy), przy czym ze względu na stosowaną metodologię MZDiN nie pokazuje pełnego obrazu regionalnego czy lokalnych rynków pracy. Jego przydatność dla polityki rozwoju zasobów ludzkich jest zatem ograniczona. $Z$ tego powodu dodatkowe, szczegółowe analizy popytowej i podażowej strony rynku, podejmowane przez obserwatoria rynku pracy, stanowią istotne źródło informacji o rynku i podstawę do planowania działań, w zakresie dostosowania kapitału ludzkiego zasobów pracy, do zapotrzebowania zgłaszanego przez pracodawców. Regionalne Obserwatorium Rynku Pracy w Łodzi działa od 2009 r. (w latach 2009-2010 miało charakter przedsięwzięcia pilotażowego), a jego funkcjonowanie zapewnione jest do końca 2013 r. Niestety obserwatoriów nie można traktować jako stałego elementu infrastruktury rynku pracy. Działają one bowiem przede wszystkim w formie projektów realizowanych w ramach Programu Operacyjnego Kapitał Ludzki i po zakończonym okresie programowania tj. po 2013 r., nie wiadomo jaki będą mieć status i jakie będzie źródło finansowania ich działalności. Ta uwaga dotyczy również RORP w Łodzi.

Schemat 1. Instytucje rynku pracy mające wpływ na kreacje kapitału ludzkiego regionu - stan obecny

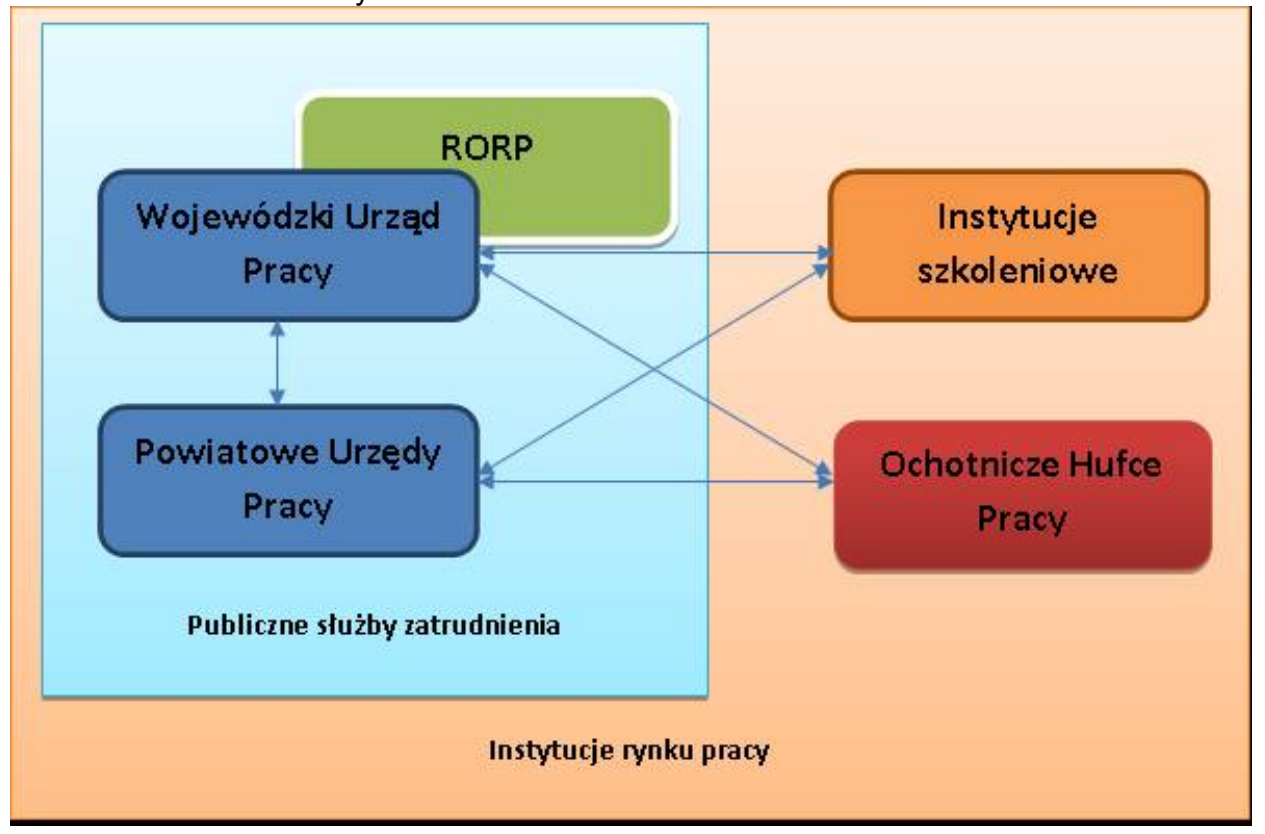

Źródło: opracowanie własne. 
RORP w Łodzi na swojej stronie internetowej publikuje w formie elektronicznej (dostępne są również wersje papierowe opracowań) wyniki swoich prac - obecnie dostępne są opracowania w ramach sześciu obszarów tematycznych: potrzeby informacyjne, analiza internetowych ofert pracy, branże przyszłości, umiejętności zawodowe, diagnoza działań, aktywność zawodowa osób niepełnosprawnych. Ich zawartość stanowi dobre uzupełnienie informacji o rynku pracy, dostępnych z innych źródeł, a co najważniejsze pokazuje specyfikę rynku pracy województwa łódzkiego, również w perspektywie średniookresowej, wskazując na potrzebne kierunki interwencji w zakresie kształtowania kapitału ludzkiego.

RORP w Łodzi poza prowadzeniem badań i analiz postawił sobie za jeden $\mathrm{z}$ celów ,stworzenie platformy wymiany informacji między podmiotami dziatajacymi po popytowej i podażowej stronie rynku pracy województwa tódzkiego, tj. instytucje rynku pracy, organy władzy samorzadowej, instytucje pośrednictwa pracy, placówki edukacyjne" ${ }^{\text {"31 }}$. Jest to ważne zadanie, gdyż jak pokazuje doświadczenie, brak takiej platformy wymiany informacji utrudnia prowadzenie racjonalnej polityki rynku pracy i rozwoju zasobów ludzkich oraz podejmowanie racjonalnych decyzji przez różnych aktorów rynku pracy województwa łódzkiego.

Ważną inicjatywą, z punktu widzenia równoważenia łódzkiego rynku pracy w wymiarze kwalifikacyjno-zawodowym, jest Obserwatorium Rynku Pracy dla Edukacji działające w strukturze Łódzkiego Centrum Doskonalenia Nauczycieli i Kształcenia Praktycznego. Jego zadaniem jest monitorowanie rynku pracy pod kątem inicjowania potrzebnych zmian w systemie kształcenia zawodowego - tak szkolnego, jak i ustawicznego. Obserwatorium Rynku Pracy dla Edukacji współpracuje z różnymi aktorami rynku pracy i prowadzi analizy w obszarze styku rynku pracy i systemu edukacji. $\mathrm{W}$ ramach prac obserwatorium przygotowano wiele opracowań - informacje o nich można znaleźć na stronie internetowej obserwatorium (http://obserwatorium.wckp.lodz.pl/index.htm). Niestety większość $\mathrm{z}$ nich jest niedostępna $\mathrm{w}$ formie elektronicznej, co utrudnia wymianę informacji i ogranicza znacząco wpływ obserwatorium na kreowanie regionalnej polityki w zakresie dostosowania kapitału ludzkiego do potrzeb rynku pracy.

Poza instytucjami rynku pracy zadanie rozwijania kapitału ludzkiego spoczywa również na pracodawcach. Niestety, jak wskazują przywoływane już wyniki badań RORP w Łodzi, poza niedostosowaniem systemu kształcenia zawodowego do potrzeb rynku pracy w województwie łódzkim, niski poziom kapitału ludzkiego jest również wynikiem zaniedbań samych pracodawców i ich stosunku do inwestowania w rozwój zasobów ludzkich, pracujących w ich podmiotach. $Z$ jednej strony pracodawcy $\mathrm{z}$ województwa łódzkiego oferują relatywnie niskie stawki wynagrodzeń, a $\mathrm{z}$ drugiej nie zapewniają wystarczającego wsparcia w zakresie podnoszenia kapitału ludzkiego, poprzez udział w szkole-

${ }^{31}$ http://obserwatorium.wup.lodz.pl/index.php/cele; Dostęp: 25.01 .2012 r. 
niach lub dofinansowanie różnych form kształcenia pozaszkolnego. Obniża to atrakcyjność łódzkiego rynku pracy i wzmaga procesy migracji wahadłowych, tym bardziej, że niedaleko znajduje się chłonny rynek warszawski, oferujący lepsze warunki. Problem pogłębia to, że pracodawcy z województwa łódzkiego często nie mają świadomości, jakim kapitałem ludzkim dysponują ich pracownicy i jakie braki w tym zakresie należałoby uzupełnic ${ }^{32}$. W rezultacie $\mathrm{w}$ procesie rekrutacji wymaga się od kandydatów do pracy formalnie wyższych kwalifikacji (np. wykształcenia wyższego) niż rzeczywiście potrzebne do realizacji zadań na danym stanowisku ${ }^{33}$. To $\mathrm{z}$ kolei wzmaga przeświadczenie wśród młodych ludzi o konieczności zdobycia wykształcenia wyższego i prowadzi do deprecjonowania roli kształcenia zawodowego na jego niższych poziomach.

Podsumowując tę część opracowania należy stwierdzić, że poziom i dostępność edukacji dorosłych tak w województwie łódzkim, jak i w całej Polsce, pozostają daleko w tyle za tym, co jest potrzebne we współczesnej gospodarce opartej na wiedzy. Podstawowymi problemami kształcenia ustawicznego są: jak zwiększyć udział obywateli w edukacji dorosłych, jak motywować do podejmowania wysiłku edukacyjnego oraz jak ukształtować system edukacji dla dorosłych.

\section{Jak adaptować systemy kształcenia zawodowego w województwie łódzkim do wymogów nowoczesnych rynków pracy}

System kształcenia zawodowego w województwie łódzkim nie jest w pełni sprawny i elastyczny, a jego stan i tempo zmian nie jest adekwatne do wymagań rozwijającego się, zmiennego rynku pracy. Można sformułować dwa podstawowe problemy edukacji, powodujące, iż nie sprzyja ona spełnianiu wymagań nowoczesnej gospodarki i oczekiwań pracodawców. Dotyczą one tak polskiej edukacji jako całości, jak i - w szczególności - edukacji w województwie łódzkim. Problem pierwszy to niedostosowanie kierunków kształcenia szkolnego do bieżących i perspektywicznych potrzeb rynku pracy. Problem drugi to niedostateczny rozwój i dostępność systemu edukacji ustawicznej.

Rekomendacje dotyczące implementacji rozwiązań, mających na celu adaptację systemów kształcenia zawodowego w województwie łódzkim do wymogów nowoczesnych rynków pracy, płynące z przeprowadzonych analiz, podzie-

\footnotetext{
${ }^{32}$ Wydaje się, że ten obszar powinien stanowić jeden z podstawowych elementów strategii CSR (Corporate Social Responsibility) budowanych głównie w dużych przedsiębiorstwach.

${ }^{33}$ Umiejętności zawodowe - teoria a praktyka. Wyniki badań $w$ województwie lódzkim, Wojewódzki Urząd Pracy w Łodzi, Łódź 2010.
} 
lono na trzy obszary: kształcenie formalne (edukację szkolną), kształcenie nieformalne (edukację ustawiczną) oraz współpracę między instytucjami rynku pracy a instytucjami systemu edukacji.

\subsection{Kształcenie formalne (edukacja szkolna)}

W obszarze kształcenia formalnego (edukacji szkolnej) należy przede wszystkim:

- zwiększyć zakres kształcenia zawodowego, zwłaszcza na poziomie średnim, przy uwzględnieniu podwyższenia udziału zajęć praktycznych, poprzez wdrożenie i wykorzystanie systemu kształcenia dualnego ${ }^{34}$;

- promować kształcenie zawodowe wśród młodzieży (obecnie znaczna część młodych ludzi, dokonując wyboru szkoły i kierunku kształcenia kieruje się przekonaniem, że jedyną drogą do osiągnięcia sukcesu zawodowego jest posiadanie dyplomu uczelni wyższej);

- wzmocnić koordynację między systemem edukacji zawodowej a rynkiem pracy:

- bieżąca, poprzez monitoring zawodów deficytowych, nadwyżkowych i znajdujących się w równowadze, dwustronne umowy między szkołami i zakładami pracy, udział partnerów społecznych w planowaniu zmian w strukturze szkolnictwa zawodowego, badanie i monitoring losów absolwentów szkół oraz kursów dokształcania oraz

- perspektywiczna, poprzez prowadzenie systematycznych studiów nad przewidywaną ewolucją zawodów i ich struktura, a także opracowanie (lub wykorzystanie istniejących) perspektywicznych prognoz zapotrzebowania na kadry w przekrojach regionalnych;

- zwiększyć zdolność adaptacyjną młodzieży do zmian na rynku pracy, poprzez jej przygotowanie do przyszłego uczestnictwa w transakcjach rynku pracy, włączone do programów szkolnych i programów działań różnych instytucji społecznych;

- zobowiązać szkoły ponadpodstawowe do zatrudniania doradców zawodowych, udzielających uczniom w wyborze zawodu i dalszych kierunków kształcenia;

- wprowadzić system obowiązkowej oceny predyspozycji młodzieży przy pomocy testów predyspozycji w ramach systemu doradztwa zawodowego. Ocena predyspozycji powinna mieć miejsce w momentach przechodzenia

${ }^{34}$ Dualny system kształcenia polega - najogólniej mówiąc - na łączeniu przyswajania wiedzy teoretycznej z praktyczną nauką zawodu. System ten stwarza naturalne mechanizmy koordynacji edukacji i rynku pracy i lepiej niż tradycyjny przygotowuje młodzież do pracy w warunkach funkcjonowania firm produkcyjnych, usługowych i innych. 
między różnymi poziomami edukacji, tak aby przy wyborze dalszej ścieżki edukacyjnej kierować się obiektywnymi przesłankami i wybierać te kierunki kształcenia, które są zgodne z predyspozycjami danej osoby, a nie panującą moda;

- wspierać rozwój kierunków ścisłych i technicznych w szkołach i na uczelniach, czemu towarzyszyć powinny działania na rzecz poprawy nauczania przedmiotów ścisłych (matematyki, fizyki i chemii) w szkołach podstawowych i ponadpodstawowych;

- zwiększyć dostępność szkół poprzez rozbudowę internatów, burs i akademików. Działania te, ze względu na swoją specyfikę, powinny mieć charakter ogólnokrajowy i być wdrażane na poziomie centralnym.

Osobnym problemem jest dostosowywanie struktury oferty szkolnictwa wyższego na terenie województwa, dla potrzeb nowoczesnych rynków pracy. Szkolnictwo wyższe ma bowiem charakter ponadlokalny (zawsze) i ponadregionalny (często), przy czym w tym przypadku decyzje dotyczące dostosowywania kierunków kształcenia do potrzeb rynku pracy, powinny zapadać na poziomie regionalnym. Podstawowy problem, wiążący się z rozwojem szkolnictwa wyższego w regionie, to dylemat:

- czy preferować tworzenie i istnienie wielu słabych naukowo i dydaktycznie ośrodków akademickich, które byłyby dostępne w sensie małych odległości od skupisk osadniczych;

- czy dążyć do rozwoju niewielkiej liczby ośrodków akademickich silnych naukowo i dydaktycznie, a za to trudniej dostępnych przestrzennie?

Dotychczasowe doświadczenia polskie wskazują na potrzebę rekomendowania rozwiązania drugiego, czyli promowania rozwoju niewielkiej liczby silnych ośrodków akademickich. W ostatnich kilkunastu latach tak w województwie łódzkim, jak i w Polsce, mieliśmy do czynienia z żywiołowym rozwojem wyższych szkół niepublicznych, działających na zasadach komercyjnych. Znacząco wzrósł udział na rynku pracy osób z wykształceniem wyższym, co należałoby przyjąć pozytywnie. Rzecz jednak w tym, iż wzrostowi ilościowemu nie towarzyszył rozwój jakościowy. Między innymi poważnie naruszona została struktura kształcenia - w szczególności zbyt mały jest odsetek studentów kształcących się w uczelniach technicznych, gdzie koszty są stosunkowo wysokie.

\subsection{Kształcenie nieformalne (edukacja ustawiczna)}

Nadrzędną zasadą kształcenia ustawicznego jest powszechność dostępu, mająca na celu zwiększenie szans zdobycia i utrzymania zatrudnienia oraz rozwoju zawodowego. W województwie łódzkim, podobnie jak w innych regionach kraju powinny być zatem wdrażane działania na rzecz ułatwienia powszechnego do- 
stępu do systemu edukacji, na co powinno wpłynąć osiaggnięcie takich celów, jak tworzenie otwartego środowiska edukacyjnego, uatrakcyjnienie procesu kształcenia oraz wspieranie aktywności obywatelskiej, zapewnienie równości szans i spójności społecznej $^{35}$. Jest to zadanie, które ma charakter regionalny i powinno być planowane i wdrażane prze instytucje szczebla regionalnego i lokalnego.

$\mathrm{W}$ regionie łódzkim niezbędna jest promocja kształcenia ustawicznego wśród pracowników i pracodawców. Promocji tej towarzyszyć musi oczywiście jego rozwój, obejmujący przede wszystkim tworzenie i rozbudowę instytucji edukacji ustawicznej, oferujących programy i formy nauczania adekwatne do potrzeb i możliwości zasobów pracy. Należy także postulować konstrukcję systemu zachęt do inwestowania w kształcenie ustawiczne, adresowanych do pracowników i pracodawców, obejmujący przede wszystkim następujące działania ${ }^{36}$ :

- upowszechnianie idei uczenia się przez całe życie, zwłaszcza przełamywanie barier świadomości osób niskokwalifikowanych, pokazywanie efektywności nakładów na edukację, kształtowanie postrzegania kształcenia w kategoriach inwestycji, a nie kosztów, propagowanie dobrych praktyk inwestowania $\mathrm{w}$ edukację;

- informację i doradztwo: rozwój informacji o rynku usług edukacyjnych i poprawa jakości oferty edukacyjnej, rozwój dostępnego powszechnie poradnictwa zawodowego dla osób, a także rozwój usług konsultacyjnych dla pracodawców;

- pomoc finansową dla osób podnoszących kwalifikacje, w szczególności adresowaną do grup o niskich dochodach i niskokwalifikowanych (np.: talony szkoleniowe, stypendia, ulgi podatkowe);

- budowanie systemu potwierdzania kwalifikacji, uzyskanych w systemie kształcenia nieformalnego i incydentalnego.

W obszarze edukacji ustawicznej w regionie łódzkim należy w szczególności:

- rozwijać jej różne formy i metody - w szerszym zakresie uwzględniając:

- kształcenie na odległość z wykorzystaniem e-nauczania;

- kształcenie modułowe, zapewniające elastyczne programy kształcenia, gdzie poszczególne jednostki można wymieniać, modyfikować, uzupełniać oraz dostosowywać do poziomu uzyskiwanych kwalifikacji, wymagań i potrzeb gospodarki oraz lokalnego rynku pracy;

- kształcenie przez praktykę, czyli z wykorzystaniem staży specjalizacyjnych i praktyk zawodowych;

${ }^{35}$ Na podstawie: Programu prac dotyczacych realizacji przyszłych celów systemu edukacji przyjętego na posiedzeniu Rady Europejskiej w dniu 14 lutego 2002 r. w ramach wniosków Prezydencji.

${ }^{36}$ Zob. Krajowa Strategia Zatrudnienia na lata 2007-2013, Ministerstwo Gospodarki i Pracy, Warszawa 2005. 
- zwiększyć rolę i znaczenie lokalnej publicznej służby zatrudnienia, poprzez wzrost $\mathrm{w}$ pakiecie aktywnych programów rynku pracy nakładów na wszelkie formy pomocy, w zakresie podnoszenia kompetencji i kwalifikacji, zwłaszcza tych, które łączą zajęcia teoretyczne z praktyką; należy również położyć nacisk na poprawę treści i sposobów adresowania szkoleń dla bezrobotnych i poszukujących pracy;

- rozwijać szeroko dostępne publiczne placówki edukacji ustawicznej, takie jak centra kształcenia ustawicznego, prowadzące ustawiczne kształcenie, dokształcanie i doskonalenie osób dorosłych, ośrodki dokształcania i doskonalenia zawodowego prowadzące dokształcanie młodocianych pracowników oraz realizujące zadania $\mathrm{z}$ zakresu doskonalenia zawodowego osób dorosłych, a także centra kształcenia praktycznego realizujące zadania z zakresu przygotowania praktycznego uczniów, wynikające z programu nauczania dla danego zawodu;

- rozwijać partnerstwa lokalne, skoncentrowane na dostosowywaniu struktury kwalifikacyjno-zawodowej lokalnych zasobów pracy do zapotrzebowania lokalnych pracodawców;

- $\quad$ szerzej włączać pracodawców do procesu kształcenia pracowników.

Należałoby również zalecić władzom samorządowym szczebla wojewódzkiego stworzenie systemu oceny jakości i wzmocnienie nadzoru nad jakością kształcenia ustawicznego w województwie. W województwie łódzkim nie istnieje (podobnie zresztą jak w pozostałych województwach) ogólnodostępna baza instytucji szkoleniowych, zawierająca w szczególności pełne informacje o tych instytucjach, jej wykładowcach, tematyce oferowanych szkoleń czy jakości świadczonych usług. Brak tych informacji poważnie utrudnia ocenę i wybór instytucji szkoleniowej. Funkcji informacyjnej nie pełnią w satysfakcjonującym stopniu obecne rejestry instytucji szkoleniowych prowadzone przez wojewódzkie urzędy pracy ${ }^{37}$. Gromadzą one bowiem informacje jedynie o tych instytucjach szkoleniowych, które są zainteresowane realizacją szkoleń dla osób bezrobotnych i poszukujących pracy, zgodnie z Ustawą z 20 kwietnia 2004 r. o promocji zatrudnienia i instytucjach rynku pracy, aby korzystać ze środków publicznych na prowadzenie tych szkoleń, takich jak np.: Fundusz Pracy, Państwowy Fundusz Rehabilitacji Osób Niepełnosprawnych, czy fundusze Unii Europejskiej. Należy przy tym zaznaczyć, iż wpis do rejestru instytucji szkoleniowej dokonywany przez wojewódzki urząd pracy nie stanowi rekomendacji instytucji szkoleniowej, ze względu na brak elementu oceny działalności instytu-

${ }^{37}$ Tryb dokonywania i wykreślania wpisu w rejestrze instytucji szkoleniowych, uaktualniania danych w rejestrze, wzór wniosku o wpis oraz wymagane dokumenty zawiera Rozporządzenie Ministra Gospodarki i Pracy z dnia 27 października 2004 r., w sprawie rejestru instytucji szkoleniowych. 
$\mathrm{cji}^{38}$. Wyznacznikiem jakości prowadzonego kształcenia w placówkach i ośrodkach prowadzących kształcenie ustawiczne $\mathrm{w}$ formach pozaszkolnych, jest jedynie akredytacja przyznawana decyzją kuratora oświaty właściwego ze względu na siedzibę placówki. Rzecz jednak w tym, że placówki prowadzące kształcenie ustawiczne w formach pozaszkolnych mogą (ale nie musza) uzyskać tę akredytację, obejmującą całość lub część prowadzonego kształcenia ${ }^{39}$. Placówka prowadząca kształcenie ustawiczne w formach pozaszkolnych, może również starać się o uzyskanie akredytacji innej instytucji (np. szkoły wyższej).

Ze względu na procesy demograficzne zachodzące na regionalnym rynku pracy województwa łódzkiego, szczególne znaczenie w procesie kształcenia ustawicznego należałoby nadać edukacji osób starszych. Edukacja ustawiczna osób starszych powinna uwzględnić trzy ważne kwestie. Pierwszą z nich jest potrzeba indywidualizacji drogi edukacyjnej, poprzez zróżnicowanie form i metod nabywania nowej lub uzupełniania dotychczasowej wiedzy i umiejętności zawodowych. Chodzi w szczególności o wprowadzenie - obok metod tradycyjnych - kształcenia na odległość czy kształcenia przy pomocy indywidualnego instruktora bądź w małych grupach, jednorodnych pod względem wieku uczestników. Sprawą drugą jest konieczność indywidualizacji programów nauczania, uwzględniających niejednorodność posiadanej wiedzy i umiejętności zawodowych osób starszych. Najlepszym sposobem jest tu wykorzystanie kształcenia modułowego i konstrukcja unikalnych programów nauczania, dostosowanych do potrzeb małych grup uczestników lub wręcz pojedynczych osób. Kwestia trzecia - być może najtrudniejsza - to wywołanie potrzeby inwestowania w siebie przez osoby starsze. $Z$ tego powodu powinien zostać opracowany projekt dodatkowych zachęt finansowych (w postaci np. talonów edukacyjnych) dla pracowników i bezrobotnych w starszym wieku, aby umożliwić im udział w programach

${ }^{38}$ Zgodnie z Ustawą z 20 kwietnia 2004 r. o promocji zatrudnienia i instytucjach rynku pracy, instytucja szkoleniowa ubiegając się o wpis do rejestru instytucji szkoleniowych, musi dostarczyć informację o:

1) tematyce prowadzonych szkoleń;

2) kadrze prowadzącej szkolenia;

3) bazie lokalowej, jej wyposażeniu i środkach dydaktycznych;

4) metodach oceny jakości szkoleń;

5) liczbie bezrobotnych i poszukujących pracy objętych szkoleniami w okresie ostatniego roku;

6) udzielanej pomocy w uzyskaniu zatrudnienia lub innej pracy zarobkowej po ukończeniu szkolenia.

${ }^{39}$ Ustawa z dnia 7 września 1991 r. o systemie oświaty. Szczegółowe warunki i tryb przyznania i cofania akredytacji określone zostały w Rozporządzeniu Ministra Edukacji Narodowej i Sportu z dnia 20 grudnia 2003 r. w sprawie akredytacji placówek i ośrodków prowadzących kształcenie ustawiczne w formach pozaszkolnych (Dz. U. Nr 227, poz. 2247). Akredytację mogą uzyskać placówki publiczne i niepubliczne, działające tak w oparciu o przepisy ustawy o systemie oświaty, jak i w oparciu o Ustawę z 2 lipca 2004 r. o swobodzie działalności gospodarczej. Ważne jest, że jedynie placówki posiadające akredytację kuratora oświaty mogą być wpisane do rejestru instytucji szkolących, mogących ubiegać się o prowadzenie szkoleń bezrobotnych finansowanych ze środków publicznych. 
uczenia się przez całe życie, celem zagwarantowania im poprawy sytuacji lub udanego powrotu na rynek pracy.

\subsection{Współpraca między instytucjami rynku pracy a instytucjami systemu edukacji}

Adaptację systemów kształcenia zawodowego do wymogów nowoczesnych rynków pracy $\mathrm{w}$ województwie łódzkim, poważnie utrudnia brak przepływu informacji oraz brak współpracy między instytucjami rynku pracy a instytucjami systemu edukacji. Uruchamianie i prowadzenie działalności edukacyjnej zarówno w formach szkolnych, jak i pozaszkolnych zbyt często nie opiera się na rzetelnej wiedzy o potrzebach rynku pracy, mimo że Regionalne Obserwatorium Rynku Pracy w Łodzi oraz Obserwatorium Rynku Pracy dla Edukacji starają się wypełnić tę lukę.

Należałoby zatem rozważyć powołanie lokalnych konwentów osób odpowiedzialnych za koordynację systemu edukacji zawodowej z potrzebami rynków pracy. Podstawowym celem konwentów byłoby tworzenie systemów monitorowania zmian gospodarczych i szybkiego reagowania na jakościowe i ilościowe zmiany zapotrzebowania na pracowników.

W skład konwentów powinni wejść:

- dyrektorzy szkół zawodowych (zasadniczych i średnich);

- rektorzy wyższych szkół zawodowych;

- przedstawiciele publicznych i niepublicznych instytucji szkoleniowych;

- przedstawiciele publicznych służb zatrudnienia;

- przedstawiciele agencji zatrudnienia;

- przedstawiciele pracodawców;

- przedstawiciele partnerstw lokalnych;

- przedstawiciele zespołu opracowującego prognozy popytu na pracę w przekrojach kwalifikacyjno-zawodowych.

Konwent powinien opracowywać:

- po pierwsze - kompleksowy, w pełni drożny system przepływu informacji, między instytucjami generującymi wyniki badań dotyczących bieżącego i perspektywicznego zapotrzebowania na pracę, a instytucjami edukacyjnymi oraz

- po drugie - sposoby upowszechniania wyników badań bieżących i perspektywicznych stanów lokalnych rynków pracy wśród mieszkańców, ze szczególnym uwzględnieniem młodzieży podejmującej decyzje o ścieżkach kariery zawodowej. 
Schemat 2. Modelowy układ instytucjonalny kreacji kapitału ludzkiego regionu

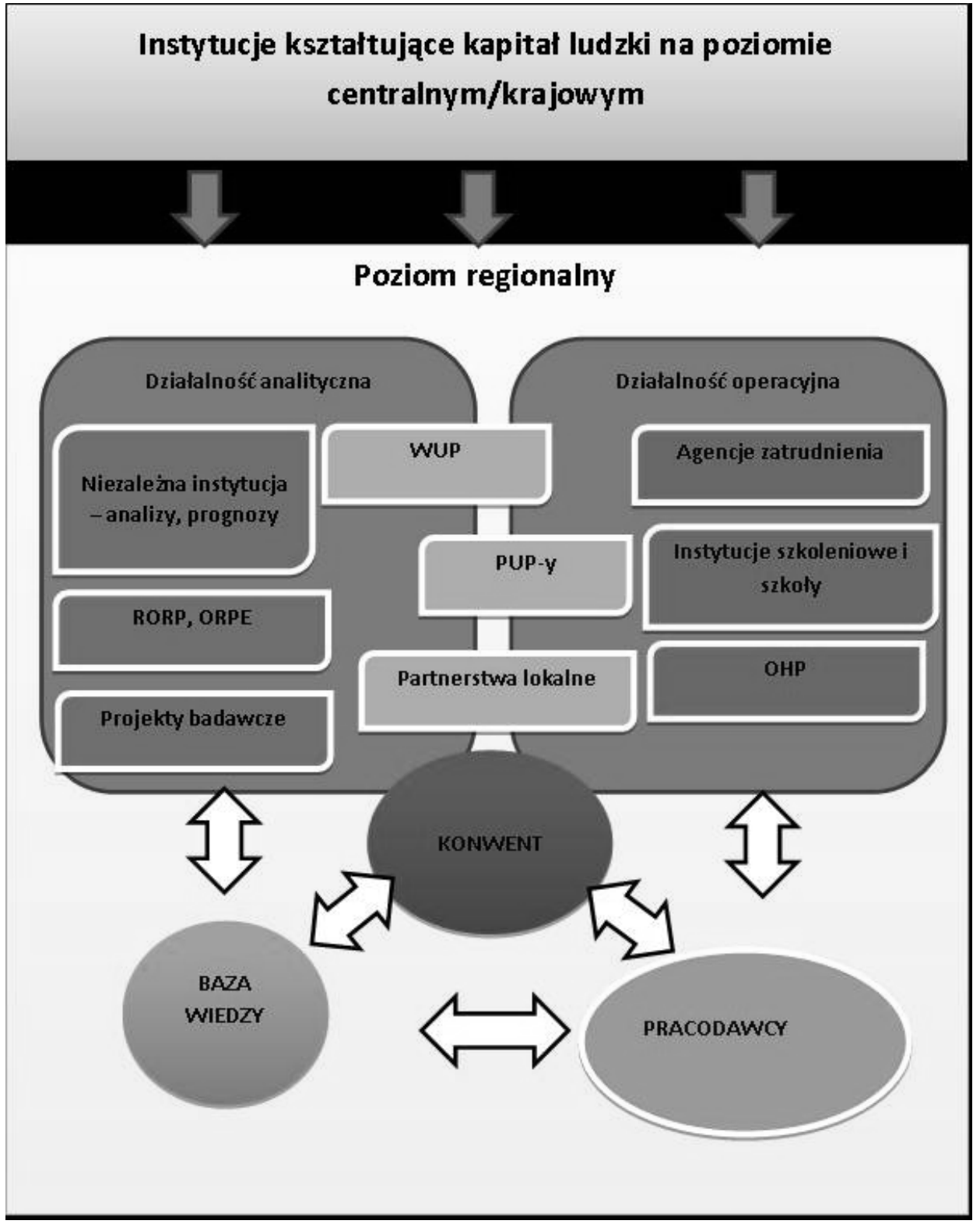

Źródło: opracowanie własne 
Zadaniem pracy stałej konwentu byłaby weryfikacja kierunków kształcenia szkolnego i pozaszkolnego o skali lokalnej i regionalnej. Konwent stanowiłby ważny element instytucjonalnej infrastruktury rynku pracy w obszarze kreowania kapitału ludzkiego dostosowanego do potrzeb regionalnej gospodarki w modelowym ujęciu zaprezentowanym na Schemacie 2.

$\mathrm{W}$ infrastrukturze tej poszczególne instytucje działające na poziomie regionalnym, przypisane są do poszczególnych obszarów, zgodnie $\mathrm{z}$ ich zakresem kompetencji. Analizy rynku pracy i zapotrzebowania na kapitał ludzki prowadzone są (w tym modelu) przez niezależną instytucję naukową, wybraną w drodze przetargu, obserwatoria (rynku pracy, edukacji) oraz $\mathrm{w}$ ramach realizowanych projektów badawczych (zazwyczaj prowadzone także przez niezależne instytucje naukowo-badawcze). Wyniki analiz zasilają bazę wiedzy dostępną online (może to być rozwinięcie koncepcji platformy wymiany informacji przedstawionej przez RORP). Baza zasilana jest również informacjami płynącymi od pracodawców, którzy aktywnie włączają się w procesy kształtowania kapitału ludzkiego regionu, a także rezultatami pracy konwentu i działalności instytucji zaliczonych do obszaru „Działalność operacyjna”. Sam konwent, wraz z WUPem, PUP-ami i partnerstwami lokalnymi, umiejscowiony jest na styku obszaru analitycznego i operacyjnego, gdyż ich kompetencje obejmują zarówno prowadzenie analiz jak i wdrażanie praktycznych rozwiązań (chociażby poprze kreowanie polityki rynku pracy). Pomiędzy obszarami i poszczególnymi instytucjami występują sprzężenia zwrotne - informacja z bazy wiedzy wpływa na działalność instytucji, a równocześnie ich działalność zmienia rynek pracy i procesy tworzenia kapitału ludzkiego, wpływając na przyrost bazy wiedzy.

\section{Bibliografia}

Allaart P., Kerkhofs M., de Kning J., Skills Obsolescence and Technological Progress: an Empirical Analysis of Expected Skill Shortages, The Economics of Skills Obsolescence, 2002 Vol. 21.

Boratyński J., Szkolnictwo zawodowe i rynek pracy województwa lódzkiego na tle kraju, Księży Młyn Dom Wydawniczy Michał Koliński, Łódź 2009.

Efektywność podstawowych form aktywizacji zawodowej realizowanych $w$ ramach programów na rzecz promocji zatrudnienia, tagodzenia skutków bezrobocia $i$ aktywizacji zawodowej w 2010 roku, Ministerstwo Pracy i Polityki Społecznej, Warszawa 2011.

Efektywność podstawowych form aktywizacji zawodowej realizowanych $w$ ramach programów na rzecz promocji zatrudnienia, tagodzenia skutków bezrobocia $i$ aktywizacji zawodowej w 2009 roku, Ministerstwo Pracy i Polityki Społecznej, Warszawa 2010. 
Efektywność podstawowych form promocji zatrudnienia i aktywizacji zawodowej bezrobotnych finansowanych z Funduszu Pracy w 2008 roku, Ministerstwo Pracy i Polityki Społecznej, Warszawa 2009.

Efektywność podstawowych form promocji zatrudnienia i aktywizacji zawodowej bezrobotnych finansowanych z Funduszu Pracy w 2007 r., Ministerstwo Pracy i Polityki Społecznej, Warszawa 2008.

Juchnowicz M., Polityka edukacyjna wobec potrzeb rynku pracy, [w:] Ksztattowanie postaw przedsiębiorczych a edukacja ekonomiczna, Wachowiak P., Dąbrowski M., Majewski B. (red.), Fundacja Promocji i Akredytacji Kierunków Ekonomicznych, Warszawa 2007.

Kapitał ludzki i społeczny regionu łódzkiego - Raport z badań ankietowych na reprezentatywnej próbie mieszkańców województwa łódzkiego, http://www.kls.uni.lodz.pl/ wyniki-badan/.

Krajowa Strategia Zatrudnienia na lata 2007-2013, Ministerstwo Gospodarki i Pracy, Warszawa 2005.

Kryńska E., Kukulak-Dolata I., Arendt Ł., Analiza regionalnego rynku pracy - metropolitarnego, subregionalnych, na potrzeby aktualizacji ,, Strategii Rozwoju Województwa Łódzkiego na lata 2007-2020”, Łódź 2011, (maszynopis).

Kryńska E. (red.), Flexicurity w Polsce. Diagnoza i rekomendacje, Ministerstwo Pracy i Polityki Społecznej, Departament Rynku Pracy, Warszawa 2009.

Kryńska E., Równowaga między elastycznościa i bezpieczeństwem na polskim rynku pracy. Jak osiagnać flexicurity? [w:] Flexicurity - między elastycznościa a bezpieczeństwem na rynku pracy, Biblioteka Monitora Prawa Pracy, Wydawnictwo C. H. Beck, Warszawa 2008.

Matusiak K. B., Arendt Ł., Kadry dla nowoczesnej gospodarki - wyzwania dla systemu edukacji [w:] Kreatywność - Innowacje - Przedsiębiorczość. SOOIPP Annual 2009, Zeszyty Naukowe Uniwersytetu Szczecińskiego nr 579, Ekonomiczne problemy usług nr 472010.

Matusiak K. B., Arendt Ł., Bendyk E., Kadry przyszłości [w:] Foresight kadr nowoczesnej gospdoarki, Matusiak K. B., Kuciński J., Gryzik A. (red.), PARP, Warszawa 2009.

Migracja pracowników - szansa czy zagrożenie? Badanie - edycja 2008 rok. Raport KPMG, KPMG, PKPP Lewiatan, 2008.

Nadwyżka i niedobór sity roboczej wedtug sektorów ekonomicznych i sekcji Polskiej Klasyfikacji Działalności (PKD). Raport za 2010 rok, Ministerstwo Pracy i Polityki Społecznej, Warszawa 2011.

Nadwyżka i niedobór siły roboczej wedtug sektorów ekonomicznych i sekcji Polskiej Klasyfikacji Działalności (PKD). Raport za 2007 rok, Ministerstwo Pracy i Polityki Społecznej, Warszawa 2008.

Okoń W., Słownik pedagogiczny, Wydawnictwo Naukowe PWN, Warszawa 1992.

Oświata i Wychowanie w roku szkolnym 2010/2011, Główny Urząd Statystyczny, Warszawa 2011.

Poszukiwany pracownik $w$ świetle ofert pracy publikowanych $w$ prasie i Internecie, Wojewódzki Urząd Pracy w Łodzi, Łódź 2010. 
Rogut A., Niedopasowania na rynku pracy $w$ województwie łódzkim $w$ zakresie zawodów, Raport opracowany w projekcie „Kapitał ludzki i społeczny jako czynniki rozwoju regionu łódzkiego, http://www.kls.uni.lodz.pl/wyniki-badan/.

Stan i perspektywy rozwoju zasobów ludzkich w branżach przyszłości regionu łódzkiego, Wojewódzki Urząd Pracy w Łodzi, Łódź 2010.

Starosta P. (red.), Kapitał ludzki i społeczny województwa łódzkiego - stan obecny, Raport opracowany w projekcie „Kapitał ludzki i społeczny jako czynniki rozwoju regionu łódzkiego, http://www.kls.uni.lodz.pl/wyniki-badan/.

Umiejętności zawodowe - teoria a praktyka. Wyniki badań w województwie łódzkim, Wojewódzki Urząd Pracy w Łodzi, Łódź 2010.

Witkowski J. (red.), Rynek pracy w województwie łódzkim Specyfika i uwarunkowania. Raport końcowy z realizacji projektu DIAGNOZA ZAWODÓW, ASM Centrum Badań i Analiz Rynku, Instytut Pracy i Spraw Socjalnych, 2007.

Akty prawne

Rozporządzeniu Ministra Edukacji Narodowej i Sportu z dnia 20 grudnia 2003 r. w sprawie akredytacji placówek i ośrodków prowadzących kształcenie ustawiczne w formach pozaszkolnych (Dz. U. Nr 227, poz. 2247).

Rozporządzenie Ministra Gospodarki i Pracy z dnia 27 października 2004 r. w sprawie rejestru instytucji szkoleniowych (Dz.U. Nr 235, poz. 2365 z 2004r.).

Ustawa z 2 lipca 2004 r. o swobodzie działalności gospodarczej (Dz.U. Nr 173, poz. 1807 z 2004r. z późn. zm.).

Ustawa z dnia 20 kwietnia 2004 r. o promocji zatrudnienia i instytucjach rynku pracy (tekst jednolity Dz.U. Nr 69, poz. 415 z 2008r. z późn. zm.).

Ustawa z dnia 7 września 1991 r. o systemie oświaty (Dz.U. Nr 95, poz. 425 z 1991 r. z późn. zm.).

Zalecenie Parlamentu Europejskiego i Rady z dnia 18 grudnia 2006 r. w sprawie kompetencji kluczowych w procesie uczenia się przez całe życie (2006/962/WE). 